NBER WORKING PAPER SERIES

\title{
THE STOCK MARKET VALUATION OF RESEARCH AND DEVELOPMENT EXPENDITURES
}

\author{
Louis K.C. Chan \\ Josef Lakonishok \\ Theodore Sougiannis \\ Working Paper 7223 \\ http://www.nber.org/papers/w7223
NATIONAL BUREAU OF ECONOMIC RESEARCH
1050 Massachusetts Avenue
Cambridge, MA 02138
July 1999

\footnotetext{
We thank Werner DeBondt, Baruch Lev, Andrei Shleifer, and participants at seminars at Michigan State University, Ohio State University, University of Michigan, and the NBER Behavioral Finance - Asset Pricing Fall 1998 meetings for comments, and Konan Chan for research assistance. All opinions expressed are those of the authors and not those of the National Bureau of Economic Research.

(C) 1999 by Louis K.C. Chan, Josef Lakonishok, and Theodore Sougiannis. All rights reserved. Short sections of text, not to exceed two paragraphs, may be quoted without explicit permission provided that full credit, including (C) notice, is given to the source.

The Stock Market Valuation of Research
} 
and Development Expenditures

Louis K.C. Chan, Josef Lakonishok, and Theodore Sougiannis

NBER Working Paper No. 7223

July 1999

JEL No. G12, G14

\begin{abstract}
$\underline{\text { ABSTRACT }}$
We examine whether stock prices fully reflect the value of firms' intangible assets, focusing on research and development (R\&D). Since intangible assets are not reported on financial statements under current U.S. accounting standards and R\&D spending is expensed, the valuation problem may be especially challenging. Nonetheless we find that historically the stock returns of firms doing R\&D on average matches the returns on firms with no R\&D. For companies engaged in $R \& D$, high $R \& D$ intensity has a distinctive effect on returns for two groups of stocks. Within the set of growth stocks, R\&D-intensive stocks tend to out-perform stocks with little or no R\&D. Companies with high R\&D relative to equity market value (who tend to have poor past returns) show strong signs of mis-pricing. In both cases the market apparently fails to give sufficient credit for firms' R\&D investments. Our exploratory investigation of the effects of advertising on returns yields similar results. We also provide evidence that $R \& D$ intensity is positively associated with return volatility, everything else equal. Insofar as the association reflects investors' lack of information about firms' R\&D activity, increased accounting disclosure may be beneficial.
\end{abstract}

Louis K.C. Chan

Department of Finance

College of Commerce

University of Illinois Urbana-Champaign

1206 South Sixth Street

Champaign, IL 62820

1-chan2@uiuc.edu

Theodore Sougiannis

Department of Accountancy

College of Commerce

University of Illinois Urbana-Champaign

1206 South Sixth Street

Champaign, IL 62820

sougiani@staff.uiuc.edu

\author{
Josef Lakonishok \\ Department of Finance \\ College of Commerce \\ University of Illinois Urbana-Champaign \\ 1206 South Sixth Street \\ Champaign, IL 62820 \\ and NBER \\ lakonish@ux1.cso.uiuc.edu
}


The market value of a firm's shares ultimately reflects the value of all its net assets. When most of the assets are physical, such as plant and equipment, inventories, or oil reserves underground, the link between asset values and stock prices is relatively apparent. Moreover, the book value of physical assets is recorded on firms' financial statements, so investors have at least such accounting values to go by. In modern economies, however, a large part of the assets of many firms is less tangible. For example, a company whose market share depends on consumer perceptions of quality or fashion may derive more of its value from its brand name or image than from its physical plant. A firm with negligible physical assets may have value that stems from a skilled work force, superior methods of production, assembly, or distribution. In such cases the intangible assets represent important sources of firm value, and yet, under generally accepted U.S. accounting principles, they are not reported in firms' financial statements. When a firm has large amounts of intangible assets, the lack of accounting information generally complicates the task of equity valuation.

One type of intangible asset, business research and development (R\&D) activity, has lately been the subject of much attention. In part, the interest reflects recent, widespread technological change, together with the dazzling growth of science- and knowledge-based industries, who are especially active in R\&D. The Russell 1000 growth index, for instance, is a widely followed stock market index. As recently as 1990, technology industries accounted for only 5 percent of the value of the index, but their proportion jumped to 20 percent by 1998 . Equally strikingly, the amount of R\&D spending in some major technology industries is larger than their earnings.

The rise in the importance of technology-oriented companies raises the question whether their stock market values reflect the large intangible assets associated with R\&D spending. In an efficient market, investors recognize sources of firm value beyond what is on the books and the stock price includes an unbiased estimate of a firm's intangible assets (such as its R\&D capital). On the other hand, several factors make the valuation of R\&D-intensive firms especially challenging. Many firms engaged in R\&D have few tangible assets. Instead, their prospects may be tied to the success of new, untested technologies and hence are highly unpredictable. Large expenditures are usually 
required at the outset, and the outcome of many research projects is far from assured. The benefits, if any, are likely to materialize only much later, while the life-cycles of resulting products may be quite short. Finally, accounting information about a firm's R\&D activity is generally of limited informativeness. Firms have some leeway in identifying what counts as an R\&D cost. All of a firm's R\&D spending is reported as one aggregate item, conveying very little information as to the nature of such activity. More importantly, U.S. generally accepted accounting principles require a firm to deduct all its R\&D expenditure as a current expense against income. This is the case even though the benefits are long-lived, and hence at least part of the spending is more appropriately treated as a capital expenditure. As a result of the expensing convention, some yardsticks commonly used by investors, such as price-earnings ratios and market-to-book ratios, are misstated. In particular, many R\&D-intensive companies may appear to be priced at unjustifiably high multiples, so they appear to be "expensive" by such criteria.

In light of these difficulties, the link between a firm's R\&D spending and its stock price performance is not likely to be clearcut. Many market commentators have argued that R\&D-intensive firms are most likely to benefit from technological in novation and therefore represent superior investments. Given the uncertainties surrounding the results of $R \& D$, however, it is also possible that the market may simply ignore any future benefits. This view would be consistent with the "functional fixation hypothesis," whereby investors mechanically accept firms' financial statements at face value, without adjusting for the long-term benefits of R\&D. If, for example, investors value a firm at a fixed multiple of earnings, the distortionary effects of R\&D expensing may lead to mispricing. Similarly, some have argued that stock market investors are myopic and fail to reward businesses for long-term investments (see, for example, Hall and Hall (1993)). In contrast, many observers have suggested that the valuations attached to R\&D-intensive technology stocks are excessive, and may reflect investors' over-optimism about the effect of R\&D on future profits. It is perhaps the case that investors are, for instance, too easily seduced by a biotechnology firm's 
promise to deliver a cure for cancer or an anti-aging drug. ${ }^{1}$

Many technology-oriented, R\&D-intensive stocks tend to have low book-to-market ratios. Examining the stock price performance of $\mathrm{R} \& \mathrm{D}$-intensive stocks would provide further evidence on a central issue in the empirical asset-pricing literature. Fama and French (1992), Lakonishok, Shleifer and Vishny (1994) find that stocks which currently have low book-to-market ratios (or "glamour" stocks) generally have poor stock price performance in the future. Evidence that R\&D-intensive stocks are mispriced would mesh with one explanation that has been offered for the poor returns on glamour stocks in general. Specifically it has been argued that investors tend to have too favorable views about the future growth prospects of glamour stocks. In this regard, investors may be excessively optimistic about the technological breakthroughs that are promised by R\&D-intensive firms.

This paper investigates whether the stock market appropriately accounts for firms' expenditures on $R \& D$. We do this by relating $R \& D$ spending to subsequent stock price performance. Section 1 of the paper begins by documenting the importance of R\&D spending, and gauges the impact of expensing $\mathrm{R} \& \mathrm{D}$ on standard valuation measures such as earnings yields and book-to-market ratios. We also provicle measures of the stock of R\&D capital, as well as the R\&D flow expense (capital amortization). Section 2 of the paper sees if measures of R\&D intensity are related to future stock returns as well as to future growth in earnings and sales. Section 3 of the paper takes a closer look at the link between returns and $R \& D$ intensity by using a factor-based model to control for size and book-to-market effects, and by looking at the impact of $R \& D$ for different categories of firm size. Also in this section we extend our analysis to another important form of intangible capital,

\footnotetext{
${ }^{1}$ A recent news story (Hansell (1998)), for example, discusses the market response to merger activity between Internet companies (who generally tend to be involved in R\&D). The article notes that "But with all the irrationally" exuberant trading in Internet companies, it was difficult to read suclı reasoning — or any rationale at all - into stock prices." Instead, "the most likely explanation for yesterday's pricing, several analysts said, was not that some investors knew too much but that many knew too little." An analyst is quoted as saying, "I think retail investors have gotten enthusiastic and haven't quite figured out what is going on here and done the math."
} 
advertising expenditures. The lack of accounting disclosure about firms' $R \& D$, in addition to having possible effects on stock prices, may also influence the level of investors' uncertainty. Accordingly, in section 4 we explore whether the volatility of stock returns is related to R\&D. A final section contains the summary and conclusions.

The evidence does not indicate that firms engaged in $R \& D$ experience superior stock price performance, compared to firms with no R\&D. Rather, the average return on the two sets of stocks is comparable. Stocks in the R\&D sample have an average annual return of 19.65 percent over the three-year period after portfolio formation, compared to 19.50 percent for firms with zero R\&D. The absence of any differences is consistent with the notion that the market price on average incorporates fully the benefits of $R \& D$ spending. Further, in many industries continued $R \& D$ investment, in the form of technological enhancements and new product development, is as much of a basic input as labor and capital. Accordingly, continued R\&D expenditures are vital to maintaining competitive position and so are not associated with superior stock price performance.

Although on average market prices fairly account for firms' R\&D spending, a closer look at the cross-sectional relation between $R \& D$ spending and stock returns uncovers additional patterns. Stocks who have high levels of R\&D relative to sales tend to be glamour stocks, but they earn larger average returns than other glamour stocks. The excess return (after adjusting for size and book-tomarket) for R\&D-intensive glamour stocks is 2.45 percent per year over the three post-formation years. In addition, stocks with high $R \& D$ relative to market value of equity (who tend to have experienced poor returns in the past) have higher average returns in the future. Excess returns for this category of stocks average 6.12 percent per year over the post-formation period. The common element in these cases is the market's failure to recognize fully the value of these firms' investments in R\&D. Two glamour stocks, one with high R\&D spending and the other with no R\&D, may appear to be equally expensive under standard criteria such as price-to-earnings and price-to-book ratios. However, the market seems to unclerestimate the future opportunities associated with the first firm's R\&D spending, relative to the growth opportunities of the second. Similarly the market. 
gives insufficient credit to past losers who continue to invest heavily in R\&D. Given the pressures such firms face to cut costs and raise earnings, a high level of $R \& D$ spending is an indicator of managers' confidence that future prospects are likely to improve. Nonetheless, the market tends to overlook such signals (just as it tends to discount other indicators of managers' optimism such as stock repurchases and insider trades). ${ }^{2}$

A variety of extensions to our analysis confirm the robustness of our main findings. Our results are not sensitive to how we adjust for size and book-to-market effects on returns. While the results are not driven solely by the behavior of small firms, the excess returns for R\&D-intensive growth stocks and R\&D-intensive past losers are larger for small firms. Since information about small firms is less readily available and they receive less coverage, the market may have a harder time tracing through the implications of $R \& D$ spending in the case of small firms. Notably, our exploratory investigation of the effects on stock returns of another important tangible asset, advertising, uncovers very similar patterns as with $R \& D$.

The similarity in the average returns of stocks doing $R \& D$ and those without $R \& D$ is consistent with the idea that investors manage to overcome the deficiencies in the current accounting treatment of intangibles and recognize the future benefits of $R \& D$. This does not mean, however, that the current accounting treatment of $\mathrm{R} \& \mathrm{D}$ is fully informative and that there are no costs from the limited disclosure of such activity. In particular we provicle some evidence that R\&D intensity is positively associated with return volatility, everything else equal. Insofar as the association reflects investor's' lack of information about the nature and outcomes of firms' R\&D activity, there may be benefits from more detailed disclosure about $R \& D$ in accounting statements.

\footnotetext{
${ }^{2}$ See, for example, Ikenberry, Lakonishok and Vermaelen (1995) for evidence on the stock price effects of share repurchases, and Lakonishok and Lee (1998) for evidence on insider trading.
} 


\section{The importance of $R \& D$ spending}

\subsection{Measures of R\&D intensity}

As background for our discussion of the market valuation of $R \& D$, this section documents the magnitude of R\&D outlays by U.S. firms. Table 1 provides summary statistics on three measures of R\&D spending: current expenditures (total outlays, representing the amount charged against income under current U.S. accounting procedures); estimated R\&D economic expense, representing the periodic amortization of the stock of R\&D capital; and lastly the estimated stock of R\&D capital. Each of the two flow measures are expressed relative to either total sales, earnings (net income), total dividends, or book value of equity. The stock of R\&D capital is compared to the book value of equity. In each of these ratios, we aggregate separately the items in the numerator and denominator. For instance, the ratio of $R \& D$ expenditures to earnings is given by the total amount of $R \& D$ expenditures summed across all eligible firms, divided by the total amount of earnings summed across the same firms. The virtue of this procedure (compared to calculating the average of the ratios across firms) is that it is insensitive to outlier cases where a firm has very low or no earnings. An added advantage is that the calculation corresponds directly to the result of a capitalization-weighted portfolio investment strategy. ${ }^{3}$

For each firm we construct measures of $R \& D$ expense as well as $R \& D$ capital from its reported history of R\&D expenditures as follows. The existing literature suggests numerous methods for measuring the stock of R\&D capital, with a wide range of estimates for the useful life of expenditures and the amortization rate. For example, estimated amortization rates range from 6 percent (Baily (1972)) to 25 percent (Hirschey (1982)). Lev and Sougiannis (1996) estimate the impact of current and past R\&D spending on earnings across a variety of ind ustries. These estimates thereby measure

\footnotetext{
${ }^{3}$ All financial information is taken from the Compustat Active and Research files. R\&D expenditure is anmual data item 46; sales is annual data jtem 12; net income is anmual data item 172; dividends to common equity are measured as annual data item 21; book value of common equity is amnual data item 60. Market value of common eqnity (price per share times number of shares outstanding) is from the (.RSP Stock Return files.
} 
the proportion of past spending that is still productive in a given year. Based on their estimates, we adopt the following tractable approximation of the stock of $\mathrm{R} \& \mathrm{D}$ capital, $R D C_{i t}$ for firm $i$ in year $t$ based on current and past R\&D expenditure $\left(R D_{i t}\right)$ :

$$
R D C_{i t}=R D_{i t}+0.8 * R D_{i t-1}+0.6 * R D_{i t-2}+0.4 * R D_{i t-3}+0.2 * R D_{i t-4} .
$$

Effectively we assume that the productivity of each dollar of spending declines linearly by twenty percent a year. Equivalently, the R\&D expense (the periodic amortization of the capital), $R E_{i t}$, is given by:

$$
R E_{i t}=0.2 *\left(R D_{i t-1}+R D_{i t-2}+R D_{i t-3}+R D_{i t-4}+R D_{i t-5}\right) .
$$

Our assumed capital amortization rate turns out to be quite close to the one used (fifteen percent) in a highly influential database compiled on R\&D activity by the National Bureau of Economic Research (see Hall et al. (1988)). ${ }^{4}$

Concentrating only on firms engaged in R\&D (panel A), R\&D spending has grown sharply in importance. As a percentage of sales, R\&D expenditures stood at 1.70 percent in 1975 and more than doubled by 1995 to 3.75 percent. As R\&D intensive firms tend to pay little or no dividends, R\&D expenditures are as much as 1.65 times cash dividends to shareholders. Finally, R\&D capital represents an important intangible asset that is not represented on firms' balance shcets. This type of intangible asset accounts for fully 29 percent of the book value of common equity in 1995.5 If the amortization rate is assumed to be 10 percent (a not unreasonable estimate, given that patent protection covers seventeen years), R\&D capital is 47 percent of book equity in 1995 . These numbers suggest that many technology-oriented glamour stocks would appear less expensive if their intangible R\&D assets were added to their book values. Not all firms carry out R\&D however, so panel $\mathbf{B}$ of the table provides the same comparisons relative to the entire set of U.S. firms. Even

\footnotetext{
${ }^{4}$ In additional unreported work, we assumed a ten percent amortization rate. The results are qualitatively unaffected.

${ }^{5}$ Note that the estimated capital stock is based on the actual outlays incurred, so the capital is valued at cost. Assuming some rate of return on R\&D over the cost of capital would lead to an even larger intangible asset.
} 
here, the importance of $R \& D$ outlays is impressive: 1995 expenditures are about 81 percent of all firms' dividends.

Business research spending is heavily concentrated in technology and science-oriented industries. As an illustration, Table 2 breaks out several industries (defined by 2-digit or 3 -digit SIC codes) of particular interest and ranks them by $1995 \mathrm{R} \& \mathrm{D}$ spending relative to industry sales. By far the highest ratio of spending is found in industry 737 (Computer programming, software and services) ${ }^{6}$ R\&D costs in this industry represent about seventeen percent of sales and two times earnings. Next in the industry ranking is the drugs and pharmaceuticals industry (SIC codes beginning with 283), where R\&D is about 12 percent of industry sales. Perhaps the recent popular impression that heavy $R \& D$ spending is associated with superior stock price performance stems in large part from the success of a few large, well-known companies drawn from these industries, such as Merck and Microsoft. Other relatively "glamorous" industries on the list include industries 357 (Computers and office equipment), 36 (Electronics and other electrical equipment excluding computers) and 48 (Communications). Another, perhaps less glamorous industry, that is also heavily involved in R\&D activity is industry 37 (Transportation equipment).

As a percentage of earnings, R\&D expenditures vary from 58 percent in industry 36 to 207 percent in industry 737. The stock of $R \& D$ capital is also large relative to the accounting book value of equity. In industry 36 , for example, R\&D capital is about 26 percent of book equity while in industry 737 R\&D capital is particularly large (more than half of book value). The magnitude

\footnotetext{
${ }^{6}$ Under current accounting rules software research costs are expensed, as in other industries, but the costs of development for software are capitalized. Development refers to the translation of research findings into plans or designs for new products or processes. In general firms are not required to report separately their expenses for research and for development. A brief perusal of the financial statements of several large, well-known software companies suggests, however, that in many cases effectively all their software R\&D costs are expensed as incurred (at least over our sample period). For example, Microsoft's balance sheet indicates that all R\&D costs are expensed and that the development portion is not material. Netscape and Symantec report sinilarly. For 1994 Lotus charged $\$ 159$ million of R\&D costs to operations and capitalized $\$ 36$ million of development costs. It reported that capitalized software costs were amortized on a straight-line basis over the specific product's economic life, generally three years.
} 
of these figures suggests that expensing $R \& D$ costs may distort conventional valuation yardsticks such as price-earnings or price-to-book ratios.

\subsection{The impact of expensing $R \& D$ costs: Is there value beneath the glamour?}

To explore further the impact on commonly-used valuation measures, we compare earnings under the current practice of immediately expensing R\&D spending with "adjusted earnings" calculated using our estimate of $R \& D$ expense (equation 2). Similarly we compare the book value of common equity with a measure of book value ("adjusted book value") which adds to the accounting book value the value of $R \& D$ capital (calculated using equation 1). The results for all firms engaged in R\&D activity are presented in panel A of Table 3. Not charging the entire amount of R\&D spending raises earnings substantially. Annual adjusted earnings are higher by about 17 percent on average over this period. In 1995, for example, the clollar difference is roughly 21 billion dollars or fifteen percent of earnings. Put another way, immediately expensing all R\&D yields a priceearnings multiple in the aggregate of 20.6 in 1995, while amortizing the capital over time yields a price-earnings ratio of 17.9 . Adding the value of the intangible $R \& D$ capital raises book value on average by 20 percent over the sample period. In 1995, for example, the increase is 8.38 percent of the market value of equity, yielding a change in the price-to-book ratio from 3.43 to 2.67.

Turning to individual R\&D-intensive industries highlights even more the potential distortions from immediately expensing R\&D. Panels B and C of Table 3 provide results for the same industries analyzed earlier. The anortization adjustment is especially striking for industry 737 (computer programming and software). The 1995 price-earnings ratio using reported earnings for this industry is 51.8 while the ratio based on adjusted earnings is less than half this amount (23.4). Similarly, the industry's price-to-book ratio moves from 6.9 to 4.4 when R\&D capital is accounted for. Arguably, our assumption of a five-year life for R\&D expenditures may be too long, given the short productcycles in the software industry. In the drugs and pharmaceuticals industry (industry 283), on the other hand, five years may not be long enough. Even in this industry, however, the amortization 
adjustments to earnings and book value are quite dramatic. With the adjustment, the price-earnings ratio comes down from 27.2 to 20.9 , while the price-to-book ratio changes from 6.2 to 4.1 .

Finally, comparisons of the adjusted and unadjusted ratios are provided in panel D for selected individual firms in 1995. For the sake of exposition, each of the selected firms has market capitalization above the median NYSE firm. Panel D shows that there are quite a few large, well-known companies whose R\&D make up a significant portion of their recorded book values or earnings. Sun Microsystems, for instance, is priced at 13.4 times unadjusted earnings but only 9.8 times adjusted earnings; its price is 2.3 times its unadjusted book value but only 1.4 times its book value including $R \& D$ capital. In these cases ignoring the value of R\&D capital may lead to serious undervaluation of these companies.

In summary, R\&D activity represents a significant and growing portion of firm resources. Several industries in particular are highly R\&D intensive. For many firms in these industries, the practice of immediately expensing R\&D outlays can have a substantial distortionary effect on carnings. By the same token, the accumulated stock of $R \& D$ capital can represent a major intangible asset relative to the reported book value of equity. If investors mechanically arrive at valuations based on such reported earnings or book values, the degree of mispricing can be substantial.

\section{R\&D activity and stock returns}

To see if the stock market correctly recognizes the expected future benefits from R\&D spending, this section implements an investment strategy based on R\&D intensity. There should be no abnormal returns from such a strategy if the market is informationally efficient and fully accounts for these future benefits. On the other hand, if the market is myopic and ignores such benefits, R\&D-intensive firms will tend to be undervalued and hence earn future abnormal returns. Conversely, if investors are overly optimistic about the prospects of firms engaged in R\&D, the stocks will be overvalued and hence investors are more likely to experience a correction in the future.

We report results using two measures of $R \& D$ intensity: R\&D expenditures relative to sales and 
relative to market value of equity. The measure of $R \& D$ intensity relative to sales is widely used in practice as an indicator of how much resources a firm devotes to $R \& D$ (see, for example, the Value Line Investment Survey). Our second indicator measures R\&D intensity relative to the market value of equity, and is in the same spirit as variables such as the earnings or book to price ratios which are commonly used in financial economics. We take all domestic common stocks listed on the New York, American stock exchanges and on Nasdaq. Portfolios are formed at the end of April each year, based on the most recently available accounting information (assuming a four-month delay between the end of a firm's fiscal year and the release of its financial statements). All eligible stocks are ranked by a measure of $R \& D$ intensity and assigned to one of five portfolios. Equally-weighted annual buy-and-hold returns are then calculated over each of the three years following portfolio formation. ${ }^{7}$

In addition, the tables report the following characteristics of each portfolio: the returns in years prior to portfolio formation; the average number of firms in the portfolio; its R\&D intensity; bookto-market ratio; sales-to-market ratio; earnings-to-price ratio; dividend yield; the average return on equity (earnings relative to the book value of equity from the prior year); and the logarithm of firm size (in millions of dollars).

\subsection{Portfolio results based on $R \& D$ relative to sales}

Table 4 provides results for portfolios sorted by $R \& D$ intensity relative to sales. In what may be a blow against the conventional wisdom that R\&D produces superior stock returns, the return performance (panel $\Lambda$ ) of firms who carry out R\&D is on average no different from those of firms without R\&D. Averaging over all the five groups of stocks doing R\&D, for example, the mean annual return in the three years following portfolio formation is 19.65 percent, compared to 19.50 percent for firms without R\&D. Put another way, run-of-the-mill cement and utility stocks on

\footnotetext{
${ }^{7}$ When a stock is delisted in the course of a year after portfolio formation, we pick up the CRSP delisting return if it is available. Thereafter we splice the stock's return with the return on the value-weighted market index until the next portfolio folmation date.
} 
average did as well as highly-touted technology stocks.

The similarity between the average returns of stocks with and without R\&D may be due to several reasons. One explanation is that the market already takes into account the impact of $R \& D$ on future profitability, so that returns on average do not vary with $R \& D$ spending. In other words, the market on average correctly values any future benefits arising from research spending. Moreover, in many science- and technology-based industries, innovation may be the competitive norm, so that there may not be any long-term rents accruing to $\mathrm{R} \& \mathrm{D}$ activity. Another explanation is that while $R \& D$ spending produced above-normal profits, they may have been offset by initial overpricing due to investors' over-optimism. A final possibility is that different sets of investors have offsetting impacts on initial stock prices. There may be myopic investors who fail to make the amortization adjustments to the earnings of R\&D-intensive firms but there may also be other investors who are overly optimistic about the prospects of such stocks. The net effect is an average rate of return no different from those of non-R\&D firms.

When we look within the group of firms engaged in research activity, there is little if any relation between $R \& D$ relative to sales and future returns in panel $A$. Raw returns are roughly the same across the five portfolios. Over the three post-formation years, for example, the most R\&D-intensive portfolio, quintile 5 , earns an average annual return of 19.52 percent, compared to the overall average of 19.65 percent per year for all R\&D firms. This is so even though the stocks in the highest-ranked portfolio are much more heavily engaged in research and development than other firms (panel C). Their R\&D activity averages roughly 23 percent of sales, far larger than the corresponding ratio for the next highest-ranked portfolio (only 6 percent for quintile portfolio 4).

Firms with a high rank by $R \& D$ relative to sales tend to be glamour stocks, with lower ratios of book-to-market equity, sales-to-price, dividends and earnings-to-price (panel C). Based on the earlier literature, such stocks are expected to have lower average returns. Yet, as panel $\mathrm{A}$ indicates, their average returns are similar to those of the other portfolios. It would appear that one set of glamour stocks, namely highly R\&D-intensive stocks, do not have the low average returns that 
usually accompany glamour investing.

Panel B takes the differences across portfolios in their value-glamour orientation into account. We follow the general approach in the literature and control for size and book-to-market effects. ${ }^{8}$ Specifically, each stock in a portfolio is assigned a control portfolio based on its ranking by size and by book-to-market. ${ }^{9}$ There are a total of thirty control portfolios, corresponding to five possible ranks by book-to-market and six possible ranks by size. The ranking by book-to-market is based on quintile breakpoints over all stocks. The breakpoints for size are based on NYSE issues only. The size categories are: groups 1 to 4 correspond to the largest four quintiles, respectively, of market capitalization; group 5 is the next-to-smallest decile of market capitalization and group 6 is the bottom decile of market capitalization. The additional breakdown of the bottom quintile of firms reflects the fact that many of the stocks who are active in $R \& D$ are generally very small. Further, since the breakpoints for the size classification are based on NYSE stocks only, the bottom quintile comprises a large number of firms. Each stock's return is measured net of the buy-and-hold return on its control portfolio.

The adjusted returns display larger differences across the R\&D portfolios. The average spread in excess returns between the highest- and lowest-ranked quintile portfolios is 3.25 percent per year over the three post-formation years. In particular, the mean excess return on the highest-ranked portfolio is 2.45 percent per year over the three post-formation years. On average, therefore, a stock which is heavily involved in R\&D relative to sales tends to do better than its peer with similar size and book-to-market ratio. Although the two stocks look equally expensive in terms of price-to-book, the market seems to overlook the benefits accruing to the stock which is investing in R\&D. In relative terms, the market appears to overestimate the prospects of the glamour stock

\footnotetext{
${ }^{8}$ For evidence that size and book-to-market are important factors for stock returns, sce Fama and French (1992) and Chan, Karceski and Lakonishok (1998).

${ }^{9}$ In order to maintain comparability with earlier research we do not include the value of R\&D capital in firms' book values of equity. In a subsequent section we use an alternative procedure for return-adjustment that is based on a three-factor model for relurus. This circumvents the issue of how to measure the value of R\&D capital
} 
with little or no R\&D and gives less consideration to the fact that the company is not investing in future opportunities.

Panel D of Table 4 looks directly at the future operating performance of the different portfolios. The details behind the calculations of growth rates in earnings and sales of the different portfolios are provided in the appendix. In terms of sales, stocks doing $R \& D$ tend to have growth rates that are slightly higher than those of stocks with no R\&D. Over the five post-formation years the sales growth rate averages 17.35 percent per year across all stocks with $R \& D$, versus 15.92 percent across all stocks without R\&D. However, the higher growth in sales does not translate into higher growth for earnings. The average annual growth rate in earnings over the five post-formation years is virtually the same for stocks with $R \& D$ and without $R \& D$ (the means across all stocks with $R \& D$ and all stocks without $R \& D$ are 10.18 percent and 10.15 percent, respectively). ${ }^{10}$ The growth rates of sales and earnings are notably higher only in the case of the most R\&D-intensive stocks (quintile portfolio 5). For this quintile the average growtl rates are 14.24 percent for earnings and 21.13 percent for sales. The high growth rates are partly due to the fact that these stocks on average have the lowest base-year earnings and sales (relative to price) of all the portfolios.

One important lesson from Table 4 thus seems to be that simply doing R\&D by itself does not on average give rise to differential stock price performance. Instead, if R\&D activity has a distinctive impact on stock returns, it appears to break out growth stocks that do R\&D from other growth stocks in general. In particular, on average a glamour stock which is highly active in R\&D tends to do better than other glamour stocks. Earlier evidence indicates that glamour stocks generally yield lower returns. One possible explanation is that they tend to be overpriced due to investors' optimism about their future growth prospects. Within the set of such glamour stocks, Table 4 says

\footnotetext{
${ }^{10}$ Note, however, that our calculation of growth rates differs from the usual measure of growth in earnings per share. In particular our calculated growth rates reflect how much earnings or sales that an investor is entitled to pej dollar of initial investment. Further we assume a buy-and-hold investment strategy, so the growth rates include the reinvestment of dividends. The average dividend yield is 1.84 percent for R\&D stocks and 2.57 percent for stocks with no R\&D. The sonewhat higher yjeld for stocks without R\&D aflects the comparison of growth rates.
} 
that there are some stocks with large R\&D spending whose returns are not lower than average. In pricing such stocks it appears that the market does not fully give credit for firms' investments in R\&D.

\subsection{Separating $\mathbf{R} \& D$ hype from $\mathbf{R} \& D$ reality}

The results from Table 4 suggest a distinction between two sets of glamour stocks. There are glamour stocks who spend on $\mathrm{R} \& \mathrm{D}$ and are thus investing in future growth opportunities, as opposed to glamour stocks who have captured investors' imaginations while not doing R\&D and whose growth prospects may be less sustainable (such as "concept" stocks). Since the amount spent on R\&D is not necessarily indicative of the productivity of such expenditures, the distinction can be sharpened. In particular, one way to judge the output of a firm's R\&D program is to see if it translates into sales revenues. We use a firm's ratio of sales to market value of equity (so that revenues are scaled by shareholders' investment) as a proxy for the productivity of $R \& D$ spending. Our idea here is that when an R\&D-intensive company has a large base of sales in place, it has an established track record of successfully translating past R\&D into revenues. ${ }^{1}$ On the other hand, when a firm has low current sales, it has no such record so R\&D offers primarily the allure of profits to come. Since investor sentiment may play a larger role in inflating valuations for such untested companies, they more closely resemble other "concept" glamour stocks with no R\&D.

Table 5 explores this intuition by separating each R\&D quintile portfolio (from Table 4) into two equally-sized groups, based on the ratio of sales to equity market valuc. Equally-weighted returns on each group are reported. As earlier studies have found, sales-to-market helps to predict future stock returns, even after controlling for size and book-to-market (Lakonishok, Shleifer and Vishny (1994). As a baseline, over the three post-formation years stocks with no R\&D and low sales-to-market ratios eam an average excess return of -1.14 percent per year while stocks with no

\footnotetext{
${ }^{11}$ Deng, Lev and Narin (1999) use patent citations as another measure of R\&D output to predict stock returns. However, data on patents are not widely accessible, and cover only a relatively small set of companies over a short period.
} 
R\&D but high sales-to-market ratios earn 1.70 percent per year. The largest mean excess return (5.29 percent per year) is earned by stocks in the top quintile of R\&D-intensity and with high sales-to-market. This group's excess return is not driven by the sales-to-market variable, since the portfolio's sales-to-market ratio is far from the highest in the table. As well, stocks in the nexthighest $\mathrm{R} \& \mathrm{D}$ quintile and with high sales-to-market also have large excess returns (4.63 percent) while their sales-to-market ratios are not outstanding.

Stocks with high R\&D intensity but with low sales-to-market, on the other hand, do not earn high mean returns. Excess returns for stocks in the top two quintiles and with low sales-to-market are close to zero. The evidence thus indicates that the returns on $R \& D$-intensive stocks with low sales-to-market on average match the returns on similarly-sized glamour stocks who do no $\mathrm{R} \& \mathrm{D}$. Table 4 says that an investor choosing glamour stocks generally does better by selecting R\&Dintensive stocks; Table 5 narrows the list further to $R \& D$-intensive stocks with an established track record in terms of sales. Conversely, firms spending on $R \& D$ but with no proven ability to generate revenues share some similarity with "concept" glamour stocks, in that they may be more prone to inflated investor expectations. Future returns for such over-hyped glamour stocks are on average disappointing.

\subsection{Portfolio results based on $\mathrm{R} \& \mathrm{D}$ relative to market value}

Table 6 reports results for $R \& D$ intensity measured as expenditures relative to market value of equity. This indicator parallels many financial measures which express a firm's characteristics per dollar invested in the stock. Hence this measure of R\&D intensity is in the spirit of evaluating investments from a shareholder's standpoint.

In general the two measures of R\&D intensity are correlated (panel C). Unlike Table 4, however, the portfolio of stocks ranked highest by R\&D relative to market tends to be populated by stocks with poor past returns (or "losers"). Over the five years prior to portfolio formation, the average annual return of stocks ranked in the top quintile by R\&D relative to market is only 9.89 percent 
(panel $A$ of Table 6). In comparison stocks with no $R \& D$ have an average return over the same period of 20.25 percent per year. Additionally, the earnings of stocks in quintile portfolio 5 are depressed, as reflected by their average earnings-to-price ratio or their average return on equity, which are the lowest in the table.

The stocks in the top quintile portfolio perform well in the years following portfolio formation. High R\&D firms earn on average a return of 26.47 percent in the first subsequent year, compared to 19.87 percent for stocks with no $\mathrm{R} \& \mathrm{D}$. The superior performance continues over the three post-formation years. The average annual rate of return over the three post-formation years is 26.19 percent for firms in the top R\&D quintile and the spread between the two extreme quintiles (11.08 percent per year on average over this period) is also large. The rebound for extreme past losers echoes the pattern uncovered by DeBondt and Thaler (1985). Firms with a history of poor performance may be subject to the kinds of extrapolative biases noted in the earlier literature. In particular, the market may discount too heavily the possibility of their future recovery. LaPorta, Lakonishok, Shleifer and Vishny (1997), for example, find a pattern of positive price reactions for value stocks around future earnings announcement dates, supporting the hypothesis that investors are too pessimistic about these firms.

In the case of stocks with high $R \& D$ intensity relative to market value, however, there is more to the story than just the subsequent recovery of past losers. Even after adjusting for size and bookto-market (pand B), their returns are still high. ${ }^{12}$ Over the post-formation period, for example, quintile portfolio 5 has an average excess return of 6.12 percent per year, yielding a mean spread of 7.83 percent per year between the extreme quintiles. ${ }^{13}$ One possible explanation for the excess returns lies in the information content of high R\&D spending for firms experiencing poor returns.

\footnotetext{
${ }^{12}$ The results in Fama and French (1996) suggest that once size and book-to-market are controlled for, long-term past losers do not earn excess returns.

${ }^{13}$ Lev and Sougiannis (1996) find similar results. They use the Fama-MacBeth (1973) methodology and estimate cross-sectional regressions of stock returns on beta, size, book-to-market, leverage, earnings yield and the ratio of R\&D capital to market equity. The coefficient on the $R \& D$ variable is positive and statistically significant.
} 
Despite their poor performance, the firms in the top quintile portfolio spend a large portion of sales revenue (in excess of eleven percent) on $R \& D$. Their managers' willingness to maintain $R \& D$ spending represents a vote of confidence that the firms' future opportunities will improve. Their beliefs are all the more credible because $R \& D$ spending directly depresses earnings, so their choice is not without pain. Moreover, there are likely to be strong pressures both internally and externally for firms with poor past returns to cut spending (including R\&D) and limit costs. As a result, the commitment of managers to long-lived investments such as R\&D suggests that these stocks' prospects may not be as bleak as investors think. Related evidence on the market under-reaction to managers' signals is found in Ikenberry, Lakonishok and Vermaelen (1995), Loughran and Ritter (1995), and Lakonishok and Lee (1998).

On a more speculative note, the nature of the investor base for R\&D-intensive technology companies may be an additional factor in determining stock prices. In particular, R\&D-intensive firms who are past losers become "orphaned" stocks with no natural underlying investor clientele. Growth investors are inclined to desert stocks once they start to perform poorly. Many value investors, on the other hand, stay away from technology stocks in general because they do not view such stocks as part of their natural investment domain. Additionally value investors may not be drawn to technology stocks because they tend to look expensive under conventional criteria. The upshot is that there may be potentially more severe underpricing when R\&D-intensive stocks experience poor performance.

To put it. in terms that parallel our results in Table 4, two value stocks, one with large R\&D spending and the other without, may look equally "cheap" by book-to-market ratios. The stock with high $R \& D$ intensity relative to market equity, however, comes with a vote of confidence from firm managers. In the latter case the market nonetheless appears to discount the favorable signal. As the outlook eventually improves and investors revise their valuations, returns on the portfolios with high $\mathrm{R} \& \mathrm{D}$ relative to market undergo a marked recovery. The growth rates in panel $\mathrm{C}$ of the table support the extent of the regained profitability for the top quintile of R\&D-intensive stocks. 
For this group earnings over the five years following portfolio formation grow by 17.13 percent, compared to 10.15 percent for firms with no $R \& D$.

\section{Additional results}

\subsection{Return adjustment using factors}

In the previous sections we adjust for size and book-to-market effects on returns by using control portfolios matched on those two characteristics. One drawback to this approach is its reliance on measured book values, which do not include the value of intangible assets. Additionally, if technology stocks always behave like growth stocks regardless of their book-to-market ratios, the adjustment based on matching portfolios may be misleading. As a check that our results are robust to the return adjustment method, in this scction we use the Fama-French $(1993,1996)$ procedure, which adjusts for the sensitivities of stock returns to market, size and book-to-market factors. Specifically, time series regressions of the form

$$
R_{p t}-R_{f t}=a_{p}+b_{p}\left[R_{M t}-R_{f t}\right]+s_{p} S M B_{t}+h_{p} H M L_{t}+\epsilon_{p t}
$$

are estimated for each quintile portfolio $p$. Here $R_{p t}-R_{f t}$ is the monthly return on the portfolio in excess of the Treasury bill rate in month $t, R_{M t}-R_{f t}$ is the excess return on the value-weighted market index, $S M B_{t}$ and $H M L_{t}$ are the returns on the Fama-French (1993) factor-mimicking portfolios for size and book-to-market, respectively. The model is estimated using monthly returns from each of the first three years following portfolio formation.

Table 7 reports the results for each measure of R\&D intensity. In panel A, portfolios are formed by the R\&D-to-sales ratio. In each year after portfolio formation the average alpha across all the R\&D portfolios is positive. In the first year the abnormal performance is 0.11 percent per montl (or 1.32 percent on an annual basis) and in the second and third years it is 0.13 percent per month (or 1.56 percent per year). As in Table 4, holding fixed size and book-to-market effects, firms who carry out R\&D earn slightly positive excess returns. 
Panel A confirms that highly R\&D-intensive stocks (measured relative to sales) generally behave like glamour stocks. The returns on the top two quintile portfolios load negatively on the bookto-market factor $H M L$ (that is, they tend to covary more strongly with stocks which have low book-to-market ratios). The popular impression is that R\&D stocks tend to be more volatile than others. In line with this notion, the R\&D portfolios' market sensitivities are generally larger than those of the portfolio comprising stocks with no R\&D. To illustrate, the top R\&D quintile portfolio has a market beta of 1.07 in the first post-formation year, compared to a beta of 0.94 for the portfolio with no R\&D.

In panel $B$, the sort by $R \& D$ relative to market value of equity produces notable differences in alphas across the quintile portfolios. In particular, the alpha for the top quintile portfolio is large and statistically significant in each of the three post-formation years. Over the first post-formation year, the excess performance for the top quintile is 0.44 percent per month. ${ }^{14}$ The spread between the extreme quintiles' alphas is 0.60 percent per month in the first year (or an annualized spread of 7.2 percent). The spread continues to be large in the second and third post-formation years as well (they are 7.44 percent and 7.56 percent per year, respectively). To sum up, our earlier findings are not sensitive to how we adjust for size and book-to-market effects.

\subsection{R\&D intensity and firm size}

Many firms who are active in R\&D are relatively small, young firms. Earlier research suggests that anomalous patterns in returns are typically more pronounced for small stocks. To address this possibility, Table 8 reports returns from each of our sorts for separate categories of firm size (equity market capitalization). The breakpoints for the size classification are based on NYSE issues only. In particular, large stocks fall in the top 3 deciles by market value of equity; mid-sized stocks belong to the next 4 deciles; small stocks are from the second and third deciles; and the last category

\footnotetext{
${ }^{14}$ In comparison the alpha for $\mathrm{R} \& \mathrm{D}$ quintile portfolio 4 is lower. Note, however, that in the top quintile portfolio R\&D spending as a fraction of market value is much higher than in the other groups, averaging 16.55 percent (see panel $\mathrm{C}$ of Table 6).
} 
comprises firms in the bottom decile of market capitalization. We report the average annual return, both unadjusted and after the adjustment using matching control portfolios, over the three years following portfolio formation.

Within each size category, there is generally little to differentiate the raw returns of firms with $R \& D$ from those of firms without $R \& D$. The average return on large firms who do $R \& D$ is about 16.60 percent per year over the three post-formation years, while the corresponding return for large firms with zero R\&D is 16.36 percent. In the case of the smallest ten percent of firms, returns for stocks with R\&D are somewhat higher than for stocks without $\mathrm{R} \& \mathrm{D}$. The average returns are 22.80 percent and 21.0 percent, respectively.

Considering firms engaged in $R \& D$, the sort by $R \& D$ relative to market value (panel $B$ ) produces differences in excess returns in all the size categories. In the group of large firms, the top $R \& D$ quintile has a mean excess return of 1.76 percent. As earlier studies on other return anomalies have found, the excess returns are notably larger for small stocks. In the smallest decile of firms, for instance, the top R\&D quintile has an average excess return of 9.89 percent per year over the post-formation period. There are generally multiple sources of information about large firms' R\&D activity. On the other hand the smallest companies tend to be less covered by analysts and overall there is less information available on them. As a result, investors may have a harder time tracing through the effects of $R \& D$ for the smallest stocks. ${ }^{15}$

\subsection{Advertising and stock returns}

While the promise of technological breakthroughs has pushed $R \& D$ capital into the limelight, there are other forms of intangible capital as well. In this section we provide an exploratory analysis

\footnotetext{
${ }^{15}$ The Fama-French regressions applied to the R\&D portfolios within each size category provide similar results as the return adjustment procedure using matching control portfolios. For example, the difference between the intercepts for the top and bottom quintile portfolios by $R \& D$ to sales is 0.22 percent per month for the smallest firms and 0.06 percent per month for the largest firms. The corresponding differences for the sort by R\&D to market equity are 1.01 percent for the snallest firms and 0.02 percent for the largest firms.
} 
of another common form of investment in intangible capital, namely, advertising. Like research and development spending, advertising expenditures have some elements of long-term investment (although the effective lifetime of advertising expenditures may be comparatively shorter). Advertising expenditures are also expensed. Empirically, advertising represents a smaller component of aggregate sales or earnings compared to R\&D. Advertising makes up about 0.9 percent of total 1995 sales of all firms, while R\&D accounts for almost twice as much (1.7 percent). Our objective here is to see if the patterns uncovered in our analysis of $R \& D$ extend to advertising.

Table 9 provides results for portfolios sorted by advertising expenditures relative to market value of equity. ${ }^{16}$ The number of firms who do advertising is roughly the same as those doing $R \& D$ (about 1200 firms on average each year report non-zero expense for either advertising or R\&D). For the firms engaged in advertising their average return over the three post-formation years (20.46 percent) is slightly higher than that of firms without advertising (18.95 percent). The difference may reflect the fact that firms who do advertising tend to be concentrated in certain industries.

Firms with high advertising relative to market equity have larger future returns than firms with low or no advertising. One characteristic of the highest-ranked firms under this measure of advertising intensity is their relatively poor past returns (14.02 percent per year on average over the prior five years, compared to an average of 19.81 percent for firms with no advertising). However they invest heavily in advertising. Echoing our results for R\&D relative to market, the returns of the advertising-intensive past losers subsequently improve. Over the three years following portfolio formation, the firms in quintile portfolio 5 have an average return of 23.63 percent (compared to 18.95 percent for firms doing no advertising). The superior performance of the portfolios with high advertising relative to market value survives the adjustment for size and book-to-market. For instance the top quintile earns an average excess return of 3.10 percent per vear over the post-

\footnotetext{
${ }^{16} \mathrm{As}$ is the case with R\&D relative to sales, the sort by advertising to sales cloes not produce notable differences in future returns across portfolios. Accordingly, for the sake of brevity these results are omitted. Unlike the sort by R\&D, however, the quintile portfolios have similar size and book-to-market characteristics. Accordingly, excess returns are also not related to the advertising to sales ratio.
} 
formation period. These results for advertising expenditures relative to market essentially agree with our findings for $R \& D$ relative to market. In particular, advertising-intensive firms with poor past performance are under strong pressures to cut costs. When such firms keep investing in their franchise value through advertising despite these pressures, they are more likely to represent cases of relative undervaluation. Nonetheless, these cases are overlooked by the market.

\section{R\&D and return volatility}

Our results suggest that on average a firm which does $R \& D$ earns a rate of return that is no different from a firm with no R\&D. Nonetheless R\&D may have effects on firms' financial performance beyond average stock returns. Given the large portion of firm resources that is devoted to research and development, it is fair to suspect that a firm's fortunes may rise or fall depending on the outcomes of its R\&D activity. Despite its importance, however, the amount of R\&D is disclosed as a single aggregate item in a firm's financial statements. While there are other sources of information about R\&D activity beyond firms' financial statements, the lack of accounting disclosure suggests that investors may not be fully informed about this vital activity. One consequence may be a high degree of uncertainty surrounding an R\&D-intensive firm's future prospects. As a result, the volatility of returns may rise with $R \& D$ spending. Even if there is little or no impact on average stock returns, then, the lack of accounting disclosure about R\&D may impose real costs on investors in the form of higher volatility. Further, higher volatility may affect the cost of capital faced by R\&D-intensive firms.

The empirical issue is whether there is any association between R\&D and return volatility. Higher volatility may be a consequence of the nature of the business in technology-based industries (where R\&D spending is mainly concentrated). In addition, many R\&D-intensive firms tend to be smaller, younger firms so there may be an association on this account. With these considerations 
in mind, we estimate a cross-sectional regression of the form:

$$
\sigma_{i t}=\gamma_{0 t}+\gamma_{1 t} L N S I Z E_{i t}+\gamma_{2 t} L N A G E_{i t}+\gamma_{3 t} R D S_{i t}+\sum_{j=1}^{L} \phi_{j t} I N D_{i j t}+\epsilon_{i t}
$$

at the end of April each year over the sample period, using all available stocks (doing $R \& D$ or not). The regression relates each stock's return volatility $\sigma_{i t}$ (the standard deviation of monthly returns based on the subsequent twelve months) to the following variables: the firm's stock market capitalization (in logarithms), LNSIZE $E_{i t}$; the firm's age (in logarithms), LNAGE $i t$; as well as its $\mathrm{R} \& \mathrm{D}$ intensity relative to sales $R D S_{i t}$. In order to capture volatility associated with business conditions in the technology sector, the regression also includes dummy variables for industries $I N D_{i j t}$. The industry classifications are based on 2-digit SIC codes and, specifically, include the technology industries considered in Table 2 (some of which are based on 3-digit codes). Then we average the estimated coefficients from the cross-sectional regressions over all portfolio-formation years and use the time series standard deviation of the coefficients to calculate ' $t$ '-statistics.

The average coefficient for R\&D intensity is 0.0963 with a ' $t$ '-statistic of 6.49 . The stocks ranked in the top quintile by $R \& D$ relative to sales have an average $R \& D$ intensity of about 23 percent (see Table 4). Compared to firms with no R\&D, therefore, the regression model predicts that monthly return volatility for highly $R \& D$ intensive companies is larger by about 2.21 percent, everything else equal. Since the average monthly volatility of returns for companies with R\&D is about 13 percent, the impact of R\&D intensity is economically important. The coefficients for the other variables in equation (4) generally conform to intuition. Firm size has a coefficient of -0.0094 (the ' $t$ '-statistic is -19.58 ) while age has a coefficient of -0.0089 (and a ' $t$ '-statistic of -8.68 ). The average $R^{2}$ for the equation is 30 percent. The results thus indicate that high $R \& D$ intensity tends to be associated with higher volatility, everything else equal. To the extent that that the limited disclosure of R\&D contributes to the higher volatility there may be a cost associated with the present accounting treatment of R\&D. 


\section{Summary and conclusions}

In modern economies many firms have large amounts of intangible assets such as brand names, patents or employees' expertise. Such intangible assets can represent a substantial portion of the market value of a firm's shares. Under U.S. generally accepted principles, however, such sources of value are not recorded on financial statements. Instead, the spending devoted to building up in tangible assets is treated as a current expense. Consequently, there can be potentially large effects on many firms' reported earnings or book values of equity. These consequences raise the question whether stock prices fully incorporate the value of intangible assets.

This question is addressed in depth in this paper, with a focus on the market valuation of R\&D capital. The rapid spread of technology, together with shifts in the structure of industry toward the science- and knowledge-based sector, have highlighted the importance of spending on R\&D.

We document that R\&D expenditures are a large and growing portion of sales and earnings. For firms engaged in R\&D, for example, the level of R\&D spending doubled from 1.70 percent of sales in 1975 to 3.75 percent in 1995 . Similarly, we estimate that in 1995 the value of R\&D capital accounts for about 29 percent of the book value of common equity for firms doing R\&D. The high level of spending suggests that large distortions can arise from expensing rather than capitalizing R\&D costs. As an illustration, immediately expensing all R\&D yields an aggregate price-earnings multiple for all R\&D firms of 20.65 in 1995 , while amortizing $R \& D$ capital results in a price-earnings multiple of 17.9 . In the case of R\&D-intensive industries such as computer software or pharmaceuticals, the impact of expensing can be even more dramatic. If investors fail to adjust standard valuation measures such as price-to-earnings or price-to-book ratios for the long-term benefits of R\&D, potentially severe mispricing may arise.

Our evidence does not support a direct link between R\&D spending and future stock returns. Indeed, the average return over all firms engaged in R\&D activity does not differ markedly from firms who do not perform R\&D. In the three-year period following portfolio formation, stocks doing R\&D have an average return of 19.65 percent per year, and stocks doing no R\&D have an average 
return of 19.50 percent. Thus it does not appear that historically a highly-touted technology stock on average outperformed a more mundane cement company. This finding is consistent with the hypothesis that the stock price fully incorporates any net benefits from R\&D. At the same time, it is also possible that the impact of different investor types may offset each other in the aggregate. Some investors may be overly optimistic about the prospects of R\&D-intensive stocks while other myopic investors may accept firms' financial statements at face value and ignore the benefits from R\&D.

The clearest evidence that high $R \& D$ plays a distinctive role arises from two sets of stocks. Stocks with high $R \& D$ relative to sales tend to be glamour stocks but they do not have the disappointing returns that glamour stocks in general earn. In particular their returns are higher by 2.45 percent per year on average over the following three years, compared to similarly-sized glamour stocks. Stocks with high $R \& D$ relative to the market value of equity tend to have notably higher average future returns. Their average excess return over the following three years is 6.12 percent per year. Our findings are not sensitive to how returns are adjusted for size and book-to-market effects.

Although two glamour stocks - one with high R\&D and the other without - may look equally expensive in terms of book-to-narket ratios, the stock which does $R \& D$ appears to be relatively undervalued by the market. Moreover, we find that the excess returns predominantly occur for R\&D intensive stocks with relatively high sales-to-market ratios. Put another way, an investor selecting glamour stocks should prefer R\&D intensive glamour stocks (everything else equal), and can do even better with R\&D intensive glamour stocks which have an established track record of translating $R \& D$ into revenues. We conjecture that $R \& D$ stocks that lack such a record resemble other glamour stocks with no R\&D in that they are more prone to inflated investor expectations.

Similarly, two stocks with high book-to-market ratios (which typically liave poor past performance) where one spends heavily on R\&D and the other has little or no R\&D, may look equally cheap under conventional valuation yardsticks. However, the market fails to give enough credit to 
the stock which invests in R\&D. Firms who continue R\&D spending despite poor past performance and pressures to cut costs, represent instances where managers remain confident in the firms' future prospects. However, the market tends to discount this information. The evidence for R\&D intensive past losers jibes with related prior evidence that the market tends to extrapolate poor past performance too far into the future, and is sluggish to revise its expectations despite the signals of informed managers.

The impact of $R \& D$ on returns is more pronounced for small stocks. There is a relative paucity of information about small stocks, particularly where intangible assets are concerned. The relative shortage of information may make it harder for investors to unravel the implications of R\&D spending for the prospects of small firms.

Public attention has centered on the importance of R\&D capital, but there are other types of intangible assets as well. Many firms spend heavily on advertising, for example. Such expenditures resemble $R \& D$ spending because they yield long-lasting benefits, but are written off as current expenses. While the bulk of our analysis looks at the relation between R\&D and stock returns, we also provide an exploratory analysis of the relation between advertising expenditures and returns. Notably, we find that the general patterns uncovered in our analysis of R\&D hold up when we examine the effect of advertising.

Although the historical record reveals little difference between the average stock price performance of R\&D stocks and stocks with no R\&D, this may not be the end of the story. The lack of disclosure in firms' financial statements about R\&D may exacerbate investors' uncertainty about future payoffs and raise return volatility. We provide evidence that R\&D intensity is associated with return volatility, after controlling for firm size, age and industry effects. Even if market prices on average incorporate the future benefits from $R \& D$, the lack of accounting information on such all important intangible asset may impose real costs on investors through increased volatility. 


\section{Appendix}

Measures of growth rates of portfolio earnings and sales

This appendix describes how we construct measures of operating performance for the individual portfolios in the analysis. Specifically, we measure each portfolio's growth rate of earnings and sales. Conventional measures of growth rates (either simple averages of individual firms' percentage growth rates, or growth rates fitted from estimated regression lines) suffer from several serious drawbacks. In the case of earnings, the level of earnings in the base period can be negative or close to zero (producing large outliers). More seriously, the conventional growth rate measures bear little if any resemblance to the underlying investment strategy which is used to generate the returns reported on the portfolios. As a result, it is not possible to make any direct comparisons between the portfolio returns earned by an investment strategy and the underlying operating performance of the portfolios.

In our case we report returns based on a buy-and-hold strategy, where the composition of the portfolios is revised each year. In parallel with this strategy we calculate growtlı rates in portfolio earnings (or sales), based on the ideas in Givoly and Lakonishok (1993), as well as Ikenberry and Lakonishok (1993). The procedure is as follows, using earnings growth as an example. In year $t$, we select stocks for a portfolio and we track the earnings on this portfolio from years $t-5$ to $t+5$. In the base year $t-5$ we invest one dollar in each of the selected stocks. For the $i$-th firm in the base year we are entitled to the proportion $\frac{1}{V_{i, t-5}}$ of its earnings, where $V_{i, t-5}$ is the market value of firm i's equity in year $t-5$ and $E_{i, t-5}$ is its total earnings available to common shareholders that year. Accordingly, the base level (at year $t-5$ ) of portfolio $p$ 's earnings, $\epsilon_{p, t-5}$, per dollar invested, is given by

$$
e_{p, t-5}=\frac{1}{N_{t-5}} \sum_{i=1}^{N_{t-5}} \frac{E_{i, t-5}}{V_{i, t-5}}
$$

where $N_{t-5}$ is the number of firms in the portfolio available for investment.

In each subsequent year $\tau$, where $t-5<\tau \leq t+5$, the earnings on the buy-and-hold portfolio, 
per dollar originally invested in the base period, is given by

$$
e_{p, \tau}=\frac{1}{N_{t-5}} \sum_{i=1}^{N_{\tau}} \frac{\prod_{l=5}^{t-\tau+1}\left(1+r_{i}[t-l, t-l+1]\right) E_{i, \tau}}{V_{i, \tau}} .
$$

The amount held in stock $i$ in year $\tau$ is given by its compound return $\prod_{l=5}^{t-\tau+1}\left(1+r_{i}[t-l, t-l+1]\right)$ from the base year to the given year, where $r_{i}[t-l, t-l+1]$ is the return on the stock between years $t-l$ and $t-l+1$. For each year $\tau$ relative to the portfolio formation year this procedure gives a time series of annual portfolio earnings per dollar originally invested. Finally we average each time series to yield eleven average values for portfolio earnings; these serve as the inputs for calculating the geometric average growth rates over the years preceding and following portfolio formation. These directly measure the operating performance of portfolios obtained from a buy-and-hold strategy and hence correspond to the returns reported in the text. Additionally the earnings for the portfolio as a whole are much less likely to be negative or very low in any given year.

Since firms entering a portfolio in a formation year $\mathrm{t}$ are not required to exist through the entire period from years $t-5$ to $t+5$, one further modification to the above procedure is necessary. As new firms enter the portfolio in year $\tau$ leading up to the formation year $(t-5<\tau \leq t)$ the total amount held in the portfolio $\sum_{i=1}^{N_{\tau}} \prod_{l=5}^{t-\tau+1}\left(1+r_{i}[t-l, t-l+1]\right)$ is equally divided across the new number of stocks. Thereafter the dollar value held in each stock is calculated based on this revised amount. Similarly as a stock drops out of the portfolio in ycar $\tau$ following the portfolio formation year $(t<\tau \leq t+5)$ we liquidate the position in the stock and equally prorate the proceeds across the remaining stocks. The subsequent value of each holding is compounded from this revised amount. 


\section{References}

Baily, Martin N., 1972, Research and development costs and returns: The U.S. pharmaceutical industry, Journal of Political Economy 80, 70-85.

Chan, Louis K. C., Yasushi Hamao, and Josef Lakonishok, 1991, Fundamentals and stock returns in Japan, Journal of Finance 46, 1739-1764.

Chan, Louis K. C., Narasimhan Jegadeesh, and Josef Lakonishok, 1996, Momentum strategies, Journal of Finance 51, 1681-1713.

Chan, Louis K. C., Jason Karceski, and Josef Lakonishok, 1998, The risk and return from factors, Journal of Financial and Quantitative Analysis 33, 159-188.

DeBondt, Werner F. M., and Richard Thaler, 1985, Does the stock market overreact?, Journal of Finance 40, 793-805.

Deng, Zhen, Baruch Lev, and Francis Narin, 1999, Science and technology as predictors of stock performance, Financial Analysts Journal, forthcoming.

Fama, Eugene F., and Kenneth R. French, 1992, The cross section of expected stock returns, Journal of Finance 47, 427-465.

Fama, Eugene F., and Kenneth R. French, 1993, Common risk factors in the returns on stocks and bonds, Journal of Financial Economics 33, 3-56.

Fama, Eugene F., and Kenneth R. French, 1996, Multifactor explanations of asset pricing anomalies, Journal of Finance 51, 55-84.

Fama, Eugene F., and James MacBeth, 1973, Risk, return and equilibrium: Empirical tests, Journal of Political Economy 81, 607--636.

Givoly, Dan, and Joscf Lakonishok, 1993, Earning growth and the firm-size anomaly, in: Guerard, John B., Jr. and Gultekin, Mustafa N. (Eds.), Handbook of Security Analyst Forecasting and Asset, Allocation, JAI Press, Greenwich CT, 163-183. 
Hall, Bronwyn H., and Robert E. Hall, 1993, The value and performance of U.S. corporations, Brookings Papers on Economic Activity 1:1993, 1-34.

Hall, Bronwyn H., Clint Cummins, Elizabeth S. Laderman, and Joy Mundy, 1988, The R\&D master file documentation, NBER Technical Working Paper no. 72.

Hansell, Saul 1998, Investor response shows quirks of Internet deals, New York Times, 24 November 1998.

Hirschey, M., 1982, Intangible aspects of advertising and R\&D expenditures, Journal of Industrial Economics 30, 375-390.

Ikenberry, David, and Josef Lakonishok, 1993, Corporate governance through the proxy contest: Evidence and implications, Journal of Business 66, 405-435.

Ikenberry, David, Josef Lakonishok, and Theo Vermaelen, 1995, Market underreaction to open market share repurchases, Journal of Financial Economics 39, 181-208.

Jensen, Michael C., 1993, The modern industrial revolution, exit, and the failure of internal control systems, Journal of Finance 48, 831-880.

Lakonishok, Josef, and Inmoo Lee, 1998, Are insiders' trades informative?, NBER working paper 6656, University of Illinois at Urbana-Champaign.

Lakonishok, Josef, Andrei Shleifer, and Robert W. Vishny, 1994, Contrarian investment, extrapolation, and risk, Journal of Finance 49, 1541-1578.

LaPorta, Rafael, Josef Lakonishok, Andrei Shleifer, and Robert Vishny, 1997, Good news for value stocks: Further evidence on market efficiency, Journal of Finance 52, 859-874.

Lev, Baruch, and Theodore Sougiannis, 1996, 'The capitalization, amortization, and value-relevance of R\&D, Journal of Accounting \& Economics 21, 107-138.

Loughran, Tim, and Jay R. Ritter, 1995, The new issues puzzle, Journal of Finance 50, 23-51. 
</ref_section> 

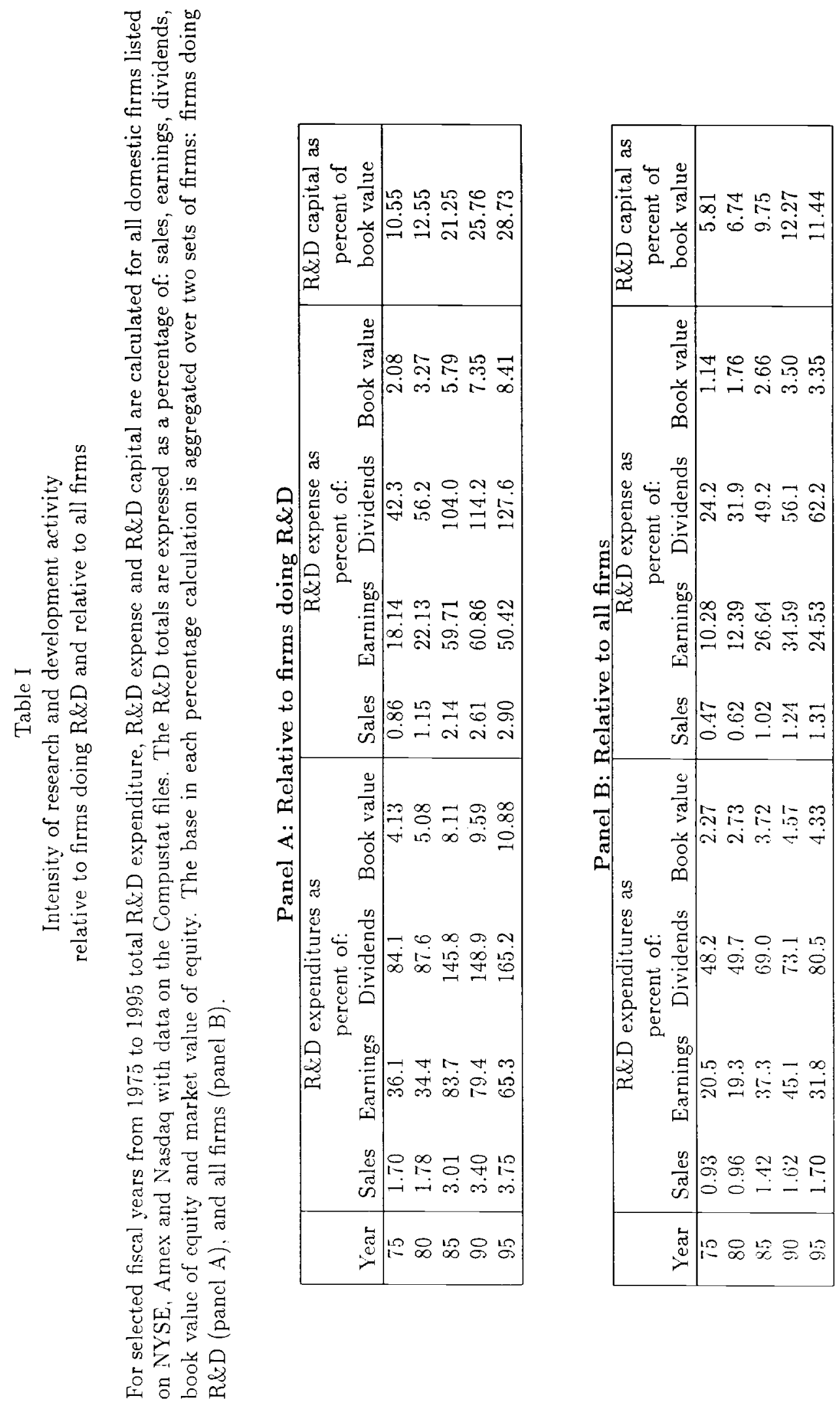
Table II

Selected industries ranked by 1995 research and development expenditure

as percent of sales

All domestic firms listed on NYSE, Amex and Nasdaq with data on the Compustat files are grouped into industry classifications based on SIC codes. For each industry total $R \& D$ expenditure, $R \& D$ expense and $R \& D$ capital are calculated and expressed as a percentage of: sales, earnings, dividends, and book value of equity, for the industry. Based on data for fiscal year 1995, results are reported for selected industries, ranked by their R\&D expenditure relative to sales, and comprising at least ten firms.

Panel A: R\&D expenditures

\begin{tabular}{|r|l|rcrcc|}
\hline & \multicolumn{1}{|c|}{$\begin{array}{c}\text { R\&D expenditure as } \\
\text { percent of: }\end{array}$} \\
SIC & \multicolumn{1}{|c|}{ Industry } & Sales & Earnings & Dividends & $\begin{array}{c}\text { Book } \\
\text { value }\end{array}$ \\
\hline 737 & Computer programming, software \& & 16.6 & 207.1 & 2833.0 & 27.5 \\
& services & & & & \\
283 & Drugs \& pharmaceuticals & 11.9 & 92.2 & 192.0 & 21.1 \\
357 & Computers \& office equipment & .7 .1 & 159.3 & 1242.4 & 21.0 \\
38 & Measuring instruments & 5.6 & 89.8 & 276.9 & 13.0 \\
36 & Electrical equipment excluding computers & 4.9 & 58.2 & 242.2 & 10.3 \\
48 & Comnunications & 3.7 & 98.1 & 80.2 & 13.7 \\
37 & Transportation equipment & 3.6 & 125.5 & 297.5 & 16.6 \\
\hline
\end{tabular}

Panel B: R\&D expense

\begin{tabular}{|r|l|ccccc|}
\hline & \multicolumn{1}{|c|}{} & \multicolumn{4}{|c|}{$\begin{array}{c}\text { R\&D expense as } \\
\text { percent of: }\end{array}$} \\
SIC & \multicolumn{1}{|c|}{$\begin{array}{c}\text { Industry } \\
\text { Sales }\end{array}$} & Earnings & Dividends & $\begin{array}{c}\text { Book } \\
\text { value }\end{array}$ \\
\hline 737 & Computer programming, software $\&$ & 6.8 & 85.2 & 1165.2 & 11.3 \\
& services & & & & \\
283 & Drugs \& pharmaceuticals & 7.9 & 61.7 & 128.5 & 14.1 \\
357 & Computers \& office equipment & 5.8 & 130.7 & 1019.8 & 17.3 \\
38 & Measuring instruments & 4.9 & 79.5 & 245.0 & 11.5 \\
36 & Electrical equipment excluding computers & 3.4 & 40.0 & 166.5 & 7.1 \\
48 & Communications & 2.9 & 78.3 & 64.0 & 10.9 \\
37 & Transportation equipment & 3.0 & 105.1 & 249.1 & 13.9 \\
\hline
\end{tabular}

Panel C: R\&D capital

\begin{tabular}{|r|l|c|}
\hline SIC & \multicolumn{1}{|c|}{ Industry } & $\begin{array}{c}\text { R\&D capital as } \\
\text { percent of } \\
\text { book value }\end{array}$ \\
\hline 737 & Computer programming, software \& services & 54.9 \\
283 & Drugs \& pharmaceuticals & 53.3 \\
357 & Computers \& office equipment & 55.9 \\
38 & Measuring instruments & 36.6 \\
36 & Electrical equipment excluding computers & 25.6 \\
48 & Communications & 36.4 \\
37 & Transportation equipment & 46.1 \\
\hline
\end{tabular}


Table III

The impact of expensing research and development spending on earnings and book value

For selected fiscal years from 1975 to 1995 total earnings net of R\&D expenditure and total earnings net of R\&D expense ("adjusted earnings") are calculated for all domestic firms listed on NYSE, Amex and Nasdaq with data on the Compustat files and who are engaged in $R \& D$ spending. Unadjusted and adjusted earnings are expressed as a percentage of market value of equity. Book value of equity, and book value of equity including R\&D capital, are also calculated and expressed as a percentage of equity market value. Panel A reports results for selected years for all firms engaged in R\&D. Panels B and C report results for the earnings and book value, respectively, of selected industries ranked by $1995 \mathrm{R} \& \mathrm{D}$ expenditure relative to sales, where each industry comprises at least ten stocks.

Panel A: Selected years

\begin{tabular}{|c|cc|cc|}
\hline & $\begin{array}{c}\text { Earnings as } \\
\text { percent of } \\
\text { market value }\end{array}$ & $\begin{array}{c}\text { Adjusted earnings as } \\
\text { percent of } \\
\text { market value }\end{array}$ & $\begin{array}{c}\text { Book value as } \\
\text { percent of } \\
\text { market value }\end{array}$ & $\begin{array}{c}\text { Adjusted book value as } \\
\text { percent of } \\
\text { market value }\end{array}$ \\
\hline 75 & 8.63 & 10.18 & 75.39 & 83.35 \\
80 & 10.38 & 11.66 & 70.31 & 79.14 \\
85 & 5.84 & 7.23 & 60.21 & 73.00 \\
90 & 6.08 & 7.21 & 50.32 & 63.28 \\
95 & 4.86 & 5.58 & 29.14 & 37.52 \\
\hline
\end{tabular}

Panel B: Earnings for selected industries, ranked by 1995 R\&D expenditure to sales

\begin{tabular}{|c|l|c|c|}
\hline SIC & \multicolumn{1}{|c|}{ Industry } & $\begin{array}{c}\text { Earnings as } \\
\text { percent of } \\
\text { market value }\end{array}$ & $\begin{array}{c}\text { Adjusted earnings } \\
\text { as percent of } \\
\text { market value }\end{array}$ \\
\hline 737 & Computer programming, software \& & 1.93 & 4.28 \\
& services & & \\
283 & Drugs \& pharmaceuticals & 3.67 & 4.79 \\
357 & Computers \& office equipment & 4.46 & 5.73 \\
38 & Measuring instruments & 4.11 & 4.53 \\
36 & Electrical equipment excluding computers & 5.44 & 6.43 \\
48 & Communications & 2.49 & 2.98 \\
37 & Transportation equipment & 5.99 & 7.21 \\
\hline
\end{tabular}

Panel C: Book value for selected industries, ranked by 1995 R\&D expenditure to sales

\begin{tabular}{|r|l|cc|}
\hline SIC & \multicolumn{1}{|c|}{$\begin{array}{c}\text { Industry } \\
\text { Book value as } \\
\text { percent of } \\
\text { market value }\end{array}$} & $\begin{array}{c}\text { Adjusted book value } \\
\text { as percent of } \\
\text { market value }\end{array}$ \\
\hline 737 & $\begin{array}{l}\text { Computer programming, software \& } \\
\text { services }\end{array}$ & 14.54 & 22.52 \\
357 & Drugs \& pharmaceuticals & 16.05 & 24.60 \\
38 & Computers \& office equipment & 33.65 & 52.46 \\
36 & Measuring instruments & 28.40 & 38.81 \\
48 & Electrical equipment excluding computers & 30.76 & 38.64 \\
37 & Communications & 17.84 & 24.33 \\
\hline
\end{tabular}




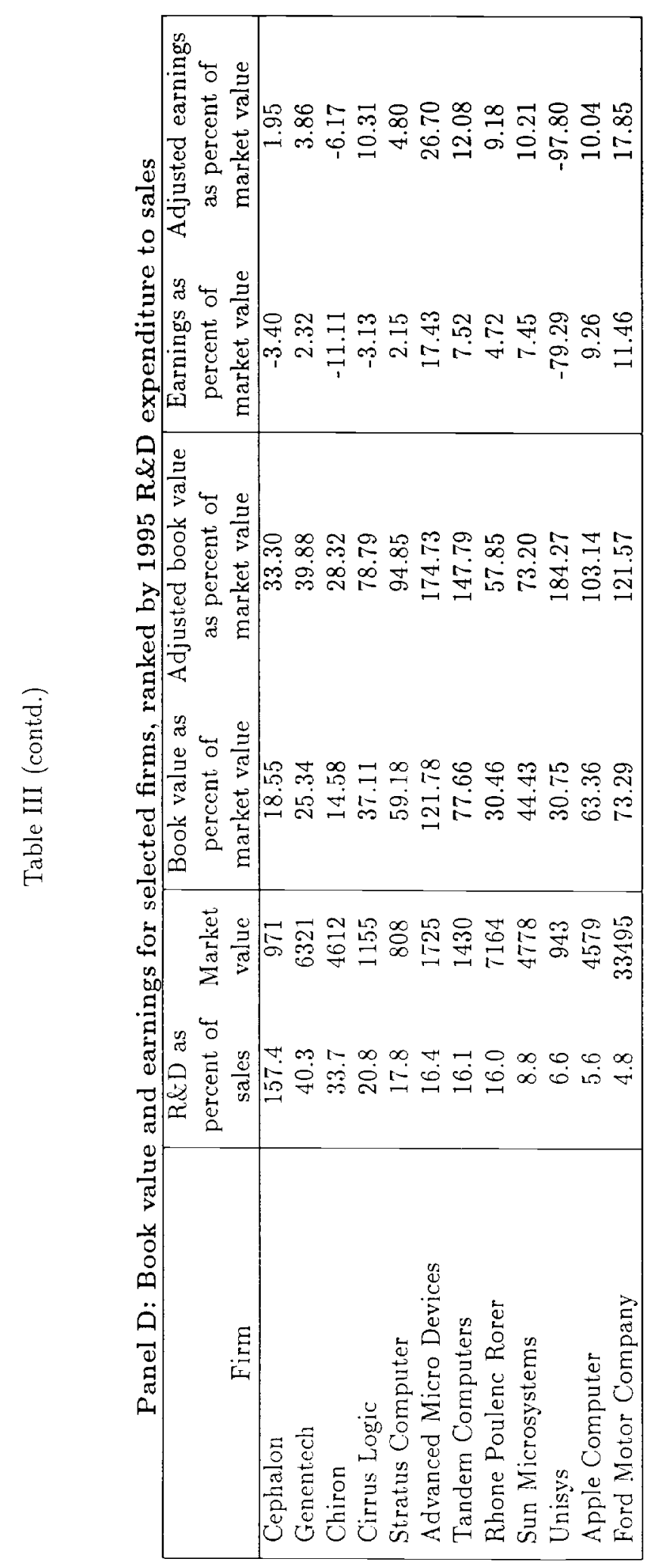


Table IV

Returns and characteristics of portfolios classified by

$\mathrm{R} \& \mathrm{D}$ expenditure relative to sales

At the end of April each year from 1975 to 1995 all stocks are ranked by their R\&D expenditure relative to sales, and assigned to one of five equally-sized portfolios. Stocks with no R\&D expenditures are assigned to a separate portfolio. The sample includes all NYSE, American Stock Exchange (AMEX) and Nasdaq domestic primary issues with coverage on the CRSP and Compustat files. In panel A, each portfolio's average annual buy-and-hold return is reported over the five years prior to portfolio formation; over each year from one to three years after portfolio formation; and averaged over the three post-formation years. Panel B reports each portfolio's average return in excess of the equally-weighted return on a control portfolio of stocks matched by firm size and book-to-market in the first through third post-formation years. Panel $\mathrm{C}$ reports characteristics of the portfolios: the average number of component stocks; the ratios of $R \& D$ expenditures to market value of equity and to sales; book value of equity relative to market value of equity; sales relative to market value of equity; earnings relative to market value of equity; annual dividends divided by market value of equity; return on equity (earnings divided by the prior year's book value of equity); and the natural logarithm of market value of equity in millions of dollars. Panel D provides annual growth rates in sales and earnings for each portfolio over the five year period following portfolio formation, using the procedure described in the appendix.

\begin{tabular}{|c|c|c|c|c|c|c|}
\hline & 1(Low) & 2 & 3 & 4 & 5 (High) & Non-R\&D \\
\hline \multicolumn{7}{|c|}{ Panel A: Returns before and after portfolio formation } \\
\hline $\begin{array}{l}\text { Average annual return over } 5 \text {-year } \\
\text { period before portfolio formation }\end{array}$ & 0.1982 & 0.1904 & 0.2038 & 0.2066 & 0.2254 & 0.2025 \\
\hline First year after portfolio formation & 0.1911 & 0.2068 & 0.2114 & 0.2167 & 0.1815 & 0.1987 \\
\hline Second year after portfolio formation & 0.1738 & 0.1936 & 0.2013 & 0.1970 & 0.1971 & 0.1916 \\
\hline Third year after portfolio formation & 0.1806 & 0.1898 & 0.2014 & 0.1984 & 0.2071 & 0.1947 \\
\hline $\begin{array}{l}\text { Average annual return over } 3 \text {-year } \\
\text { period after portfolio formation }\end{array}$ & 0.1818 & 0.1967 & 0.2047 & 0.2040 & 0.1952 & 0.1950 \\
\hline \multicolumn{7}{|c|}{ Panel B: Excess returns after portfolio formation } \\
\hline First year after portfolio formation & -0.0058 & 0.0121 & 0.0185 & 0.0317 & 0.0016 & -0.0018 \\
\hline Second year after portfolio formation & -0.0116 & 0.0092 & 0.0208 & 0.0254 & 0.0327 & 0.0036 \\
\hline Third year after portfolio formation & -0.0066 & 0.0043 & 0.0198 & 0.0235 & 0.0391 & 0.0060 \\
\hline $\begin{array}{l}\text { Average annual excess return over } \\
3 \text {-year period after portfolio formati }\end{array}$ & -0.0080 & 0.0085 & 0.0197 & 0.0269 & 0.0245 & 0.0026 \\
\hline \multicolumn{7}{|c|}{ Panel C: Characteristics of portfolios } \\
\hline Average no. of firms & 237.8 & 238.0 & 238.3 & 238.3 & 238.6 & 1856.5 \\
\hline R\&D to sales & 0.0046 & 0.0136 & 0.0289 & 0.0571 & 0.2262 & 0.0000 \\
\hline R\&D to market value & 0.0130 & 0.0321 & 0.0569 & 0.0807 & 0.1088 & 0.0000 \\
\hline Book-to-market & 0.8997 & 0.8511 & 0.8001 & 0.7033 & 0.5408 & 0.9008 \\
\hline Sales-to-market & 3.1756 & 2.5879 & 2.3021 & 1.7118 & 1.0297 & 2.7738 \\
\hline Earnings-to-price & 0.0800 & 0.0759 & 0.0684 & 0.0537 & 0.0058 & 0.0797 \\
\hline Dividend yield & 0.0258 & 0.0243 & 0.0208 & 0.0153 & 0.0057 & 0.0257 \\
\hline Return on equity & 0.1088 & 0.1090 & 0.1069 & 0.0983 & 0.0183 & 0.1060 \\
\hline Log Size & 4.6863 & 4.6456 & 4.5959 & 4.5396 & 4.2323 & 4.4437 \\
\hline \multicolumn{7}{|c|}{ Panel D: Average annual growth rates after portfolio formation } \\
\hline $\begin{array}{l}\text { Arnual sales growth over } \\
5 \text { post-formation years }\end{array}$ & 0.1545 & 0.1559 & 0.1686 & 0.1773 & 0.2113 & 0.1592 \\
\hline $\begin{array}{l}\text { Annual earnings growth over } \\
5 \text { post-formation years }\end{array}$ & 0.0728 & 0.1083 & 0.1084 & 0.0772 & 0.1424 & 0.1015 \\
\hline
\end{tabular}



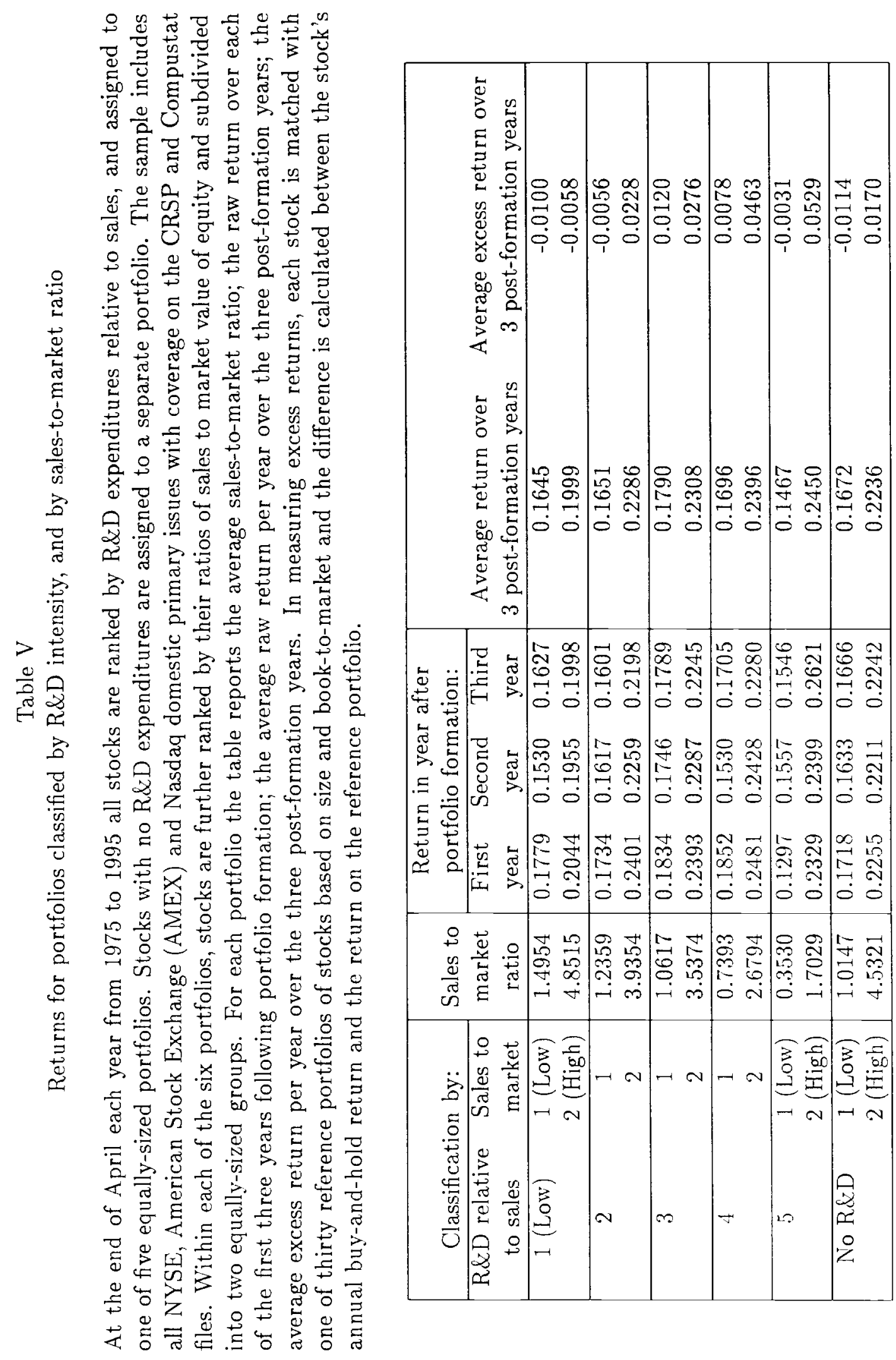
Table VI

Returns and characteristics of portfolios classified by

R\&D expenditure relative to equity market value

At the end of April each year from 1975 to 1995 all stocks are ranked by their R\&D expenditure relative to the market value of equity, and assigned to one of five equally-sized portfolios. Stocks with no R\&D expenditures are assigned to a separate portfolio. The sample includes all NYSE, American Stock Exchange (AMEX) and Nasdaq domestic primary issues with coverage on the CRSP and Compustat files. In panel A, each portfolio's average annual buy-and-hold return is reported over the five years prior to portfolio formation; over each year from one to three years after portfolio formation; and averaged over the three post-formation years. Panel B reports each portfolio's average return in excess of the equally-weighted return on a control portfolio of stocks matched by firm size and book-to-market in the first through third post-formation years. Panel C reports characteristics of the portfolios: the average number of component stocks; the ratios of R\&D expenditures to market value of equity and to sales; book value of equity relative to market value of equity; sales relative to market value of equity; earnings relative to market value of equity; annual dividends divided by market value of equity; return on equity (earnings divided by the prior year's book value of equity); and the natural logarithm of market value of equity in millions of dollars. Panel D provides annual growth rates in sales and earnings for each portfolio over the five year period following portfolio formation, using the procedure described in the appendix.

\begin{tabular}{|c|c|c|c|c|c|c|}
\hline & 1(Low) & 2 & 3 & 4 & 5 (High) & Non-R\&D \\
\hline \multicolumn{7}{|c|}{ Panel A: Returns before and after portfolio formation } \\
\hline $\begin{array}{l}\text { Average annual return over } 5 \text {-year } \\
\text { period before portfolio formation }\end{array}$ & 0.2924 & 0.2460 & 0.2095 & 0.1687 & 0.0989 & 0.2025 \\
\hline First year after portfolio formation & 0.1582 & 0.1782 & 0.1927 & 0.2135 & 0.2647 & 0.1987 \\
\hline Second year after portfolio formation & 0.1401 & 0.1658 & 0.1869 & 0.2198 & 0.2534 & 0.1916 \\
\hline Third year after portfolio formation & 0.1551 & 0.1677 & 0.1923 & 0.1975 & 0.2677 & 0.1947 \\
\hline $\begin{array}{l}\text { Average annual return over } 3 \text {-year } \\
\text { period after portfolio formation }\end{array}$ & 0.1511 & 0.1706 & 0.1906 & 0.2103 & 0.2619 & 0.1950 \\
\hline \multicolumn{7}{|c|}{ Panel B: Excess returns after portfolio formation } \\
\hline First year after portfolio formation & -0.0177 & -0.0040 & 0.0051 & 0.0161 & 0.0585 & -0.0018 \\
\hline Second year after portfolio formation & -0.0220 & -0.0023 & 0.0125 & 0.0353 & 0.0552 & 0.0036 \\
\hline Third year after portfolio formation & -0.0116 & -0.0038 & 0.0140 & 0.0139 & 0.0699 & 0.0060 \\
\hline $\begin{array}{l}\text { Average annual excess return over } \\
3 \text {-year period after porfolio formation }\end{array}$ & -0.0171 & -0.0034 & 0.0105 & 0.0218 & 0.0612 & 0.0026 \\
\hline \multicolumn{7}{|c|}{ Panel C: Characteristics of portfolios } \\
\hline Average no. of firms & 237.8 & 238.0 & 238.3 & 238.3 & 238.6 & 18.56 .5 \\
\hline $\mathrm{R} \& \mathrm{D}$ to sales & 0.0210 & 0.0461 & 0.0660 & 0.0838 & 0.1137 & 0.0000 \\
\hline$R \& D$ to market value & 0.0068 & 0.0188 & 0.0358 & 0.0644 & 0.1655 & 0.0000 \\
\hline Book-to-market & 0.5832 & 0.6626 & 0.7020 & 0.7934 & 1.0523 & 0.9008 \\
\hline Sales-to-market & 1.6223 & 1.8656 & 1.9622 & 2.2467 & 3.1035 & 2.7738 \\
\hline Earnings-to-price & 0.0651 & 0.0666 & 0.0618 & 0.0590 & 0.0311 & 0.0797 \\
\hline Dividend yield & 0.0196 & 0.0200 & 0.0189 & 0.0179 & 0.0155 & 0.0257 \\
\hline Return on equity & 0.1252 & 0.1129 & 0.0966 & 0.0779 & 0.0288 & 0.1060 \\
\hline Log Size & 5.0420 & 4.7837 & 4.6911 & 4.4042 & 3.7802 & 4.4437 \\
\hline \multicolumn{7}{|c|}{ Panel D: A verage annual growth rates after portfolio formation } \\
\hline $\begin{array}{l}\text { Annual sales growth over } \\
5 \text { post-formation years }\end{array}$ & 0.1867 & 0.1741 & 0.1685 & 0.1716 & 0.1667 & 0.1592 \\
\hline $\begin{array}{l}\text { Annual earnings growth over } \\
5 \text { post-formation years }\end{array}$ & 0.0730 & 0.0641 & 0.0644 & 0.0985 & 0.1713 & 0.1015 \\
\hline
\end{tabular}




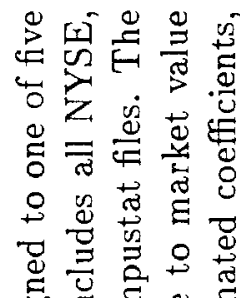

.0.

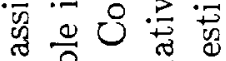

吕

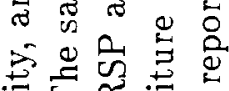

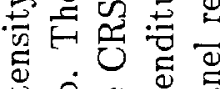

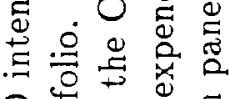

莺

造范它

王

¿ 0.

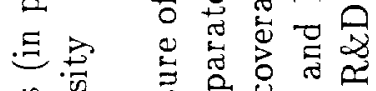

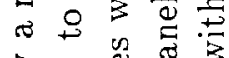

จ. $50.2 \%$

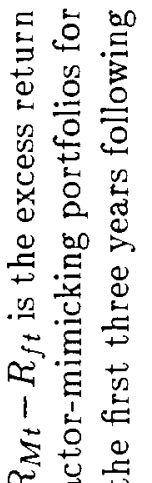

焉

$\therefore \div$

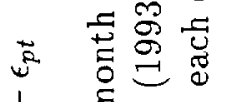

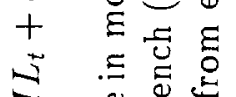

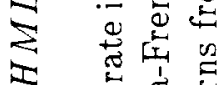

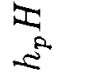

$+\quad 0$ 范

0

फ

$+\frac{0}{5} \stackrel{5}{5}$

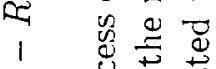

¿

$. \Xi \pm$

$\because \sum$.

늉

吕导

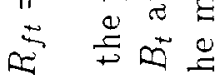

Бํㄹ

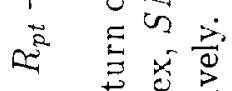

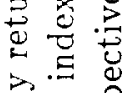

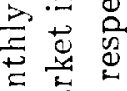

总苛

듕

.

$=$

थ

1 웅

눌

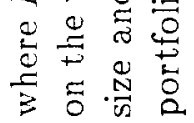

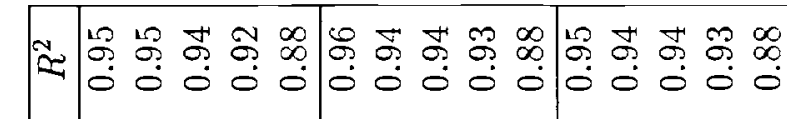
ע 2 ำ

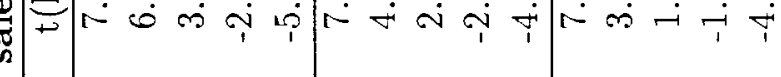

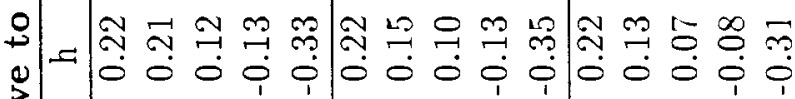
氙

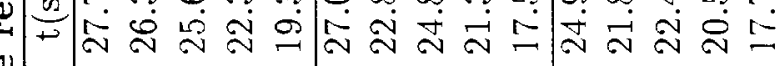

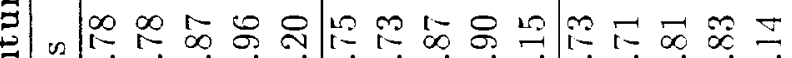

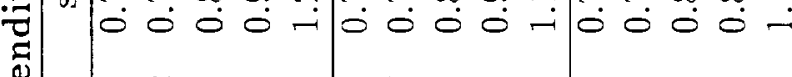

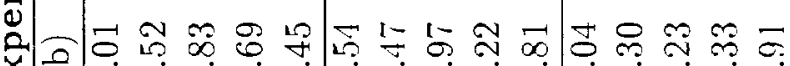

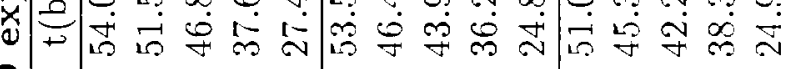
娄

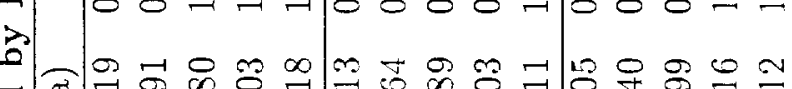

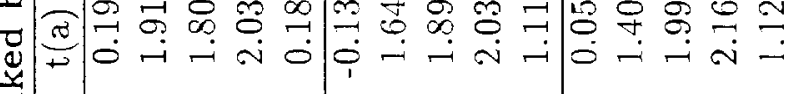

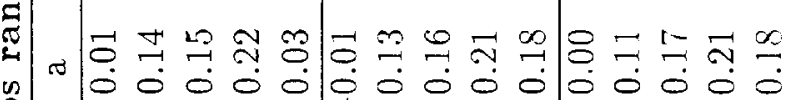

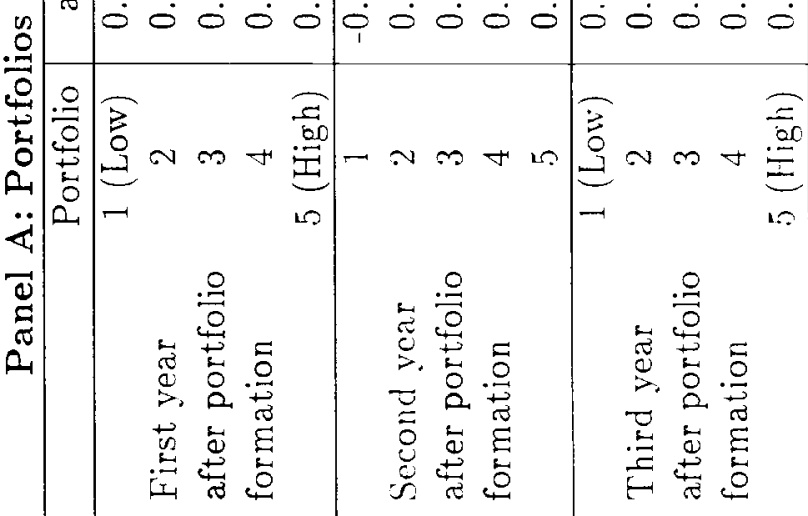




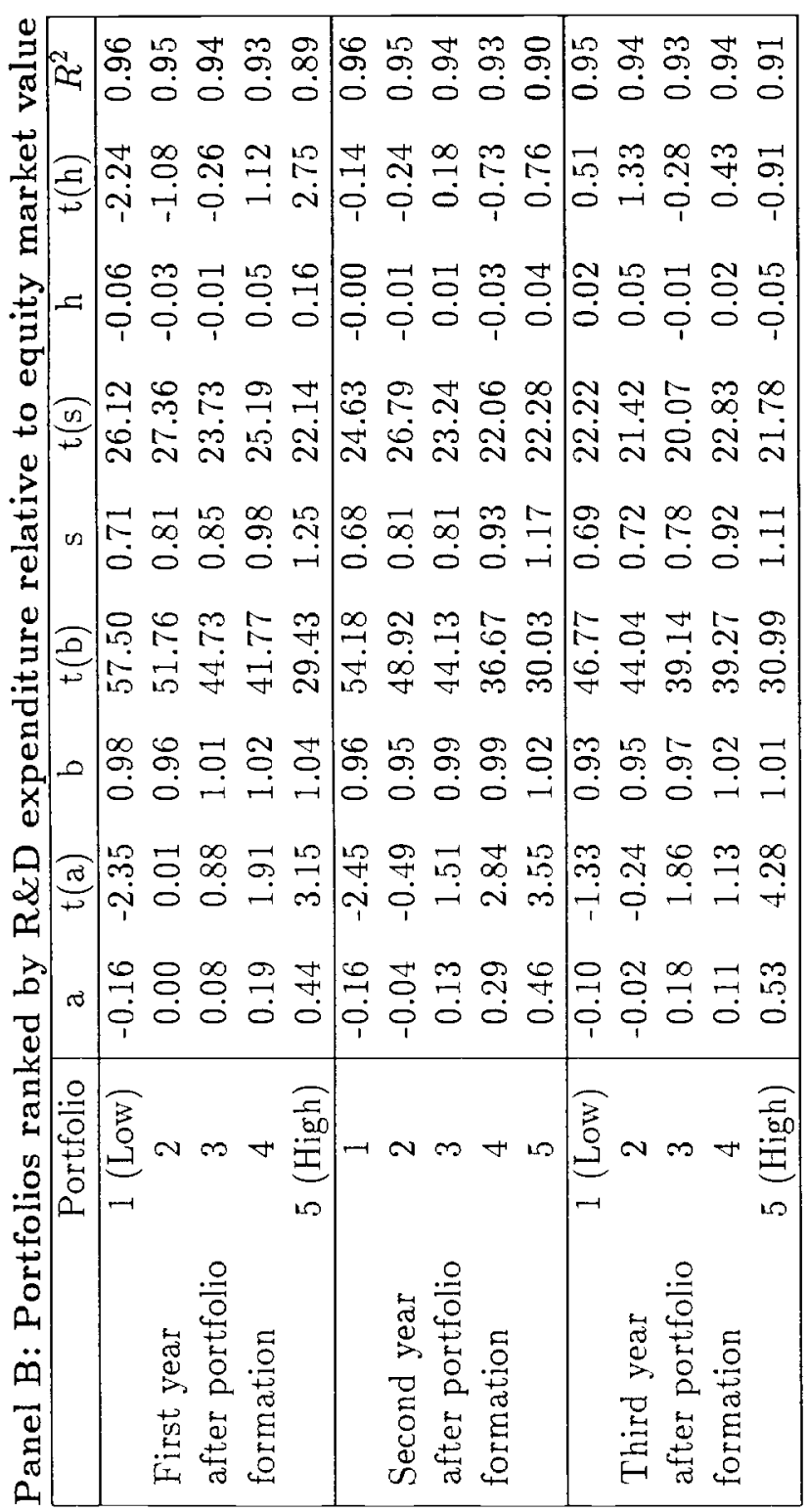




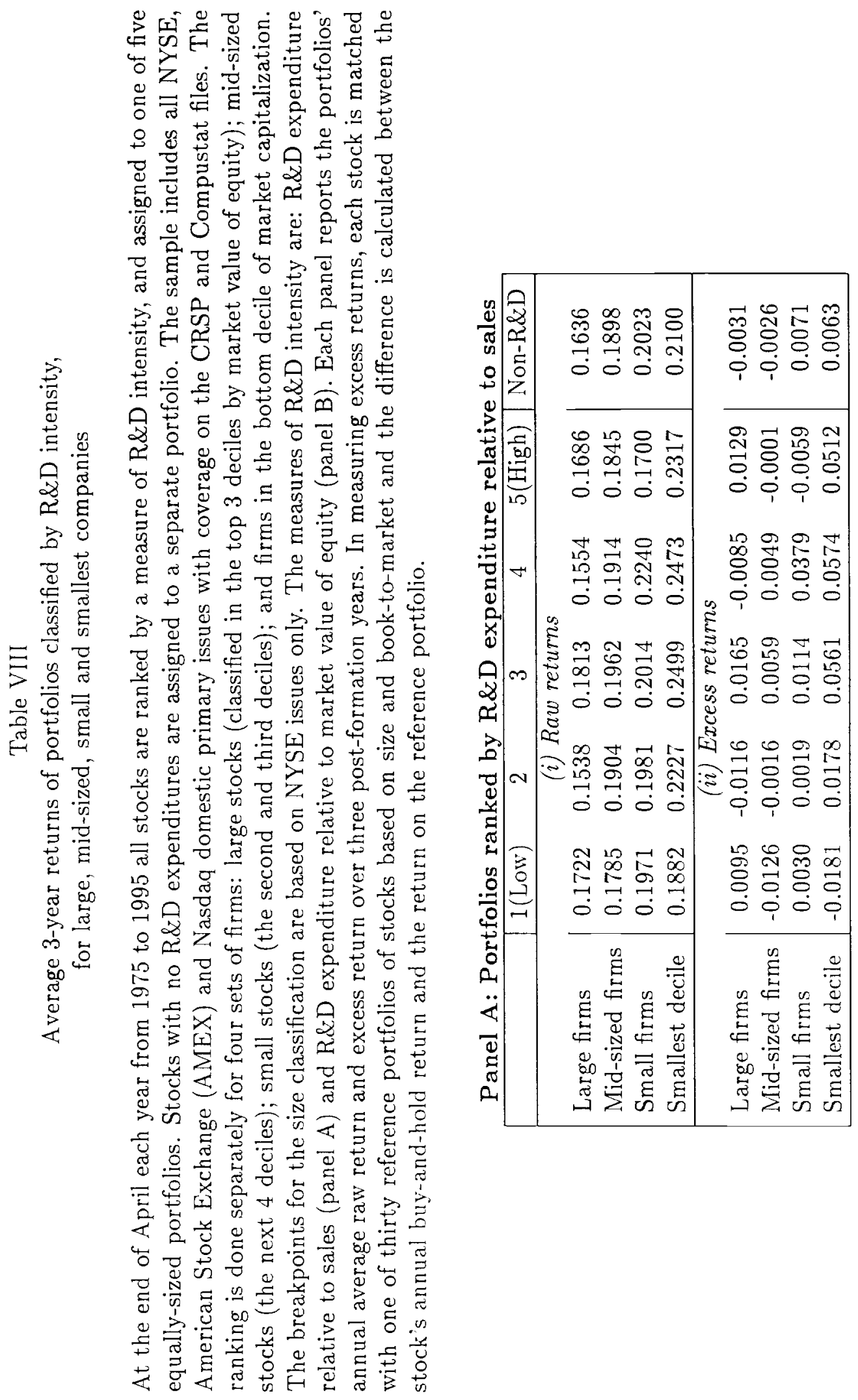




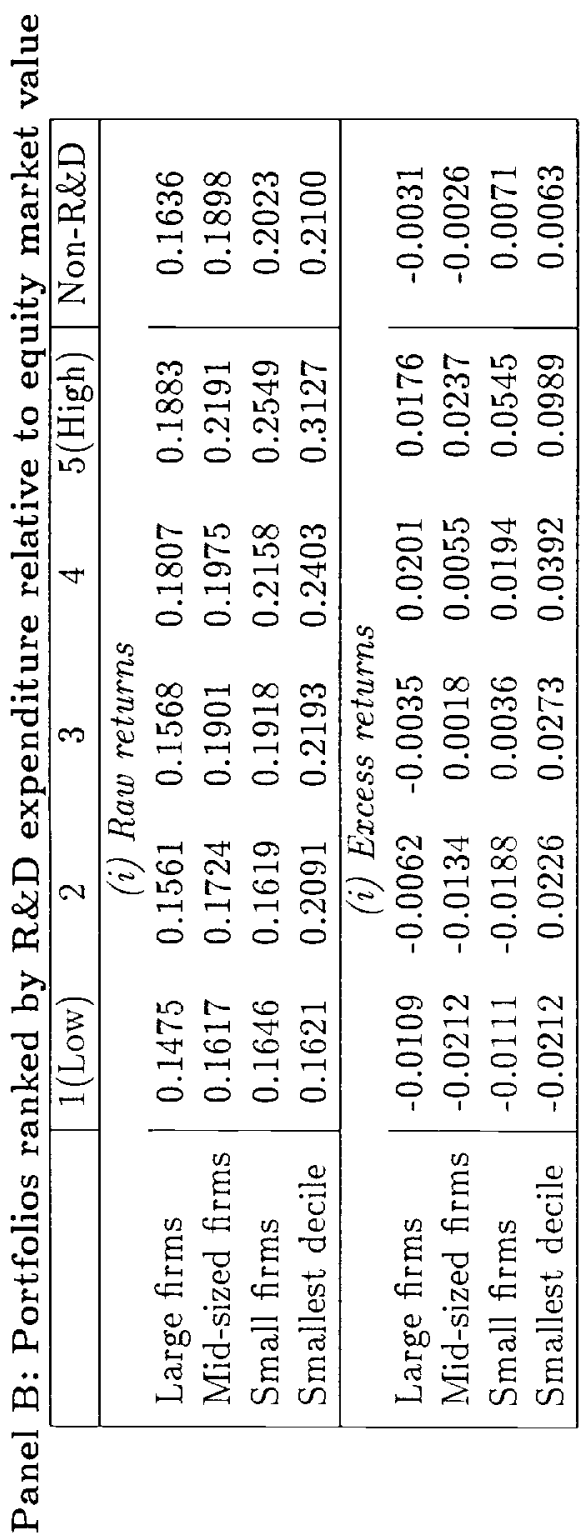


Table IX

Returns and characteristics of portfolios classified by advertising expenditure relative to equity market value

At the end of April each year from 1975 to 1995 all stocks are ranked by their advertising expenditure relative to the market value of equity, and assigned to one of five equally-sized portfolios. Stocks with no advertising expenditures are assigned to a separate portfolio. The sample includes all NYSE, American Stock Exchange (AMEX) and Nasdaq domestic primary issues with coverage on the CRSP and Compustat files. In panel A, each portfolio's average annual buy-and-hold return is reported over the five years prior to portfolio formation; over each year from one year to three years after portfolio formation; and averaged over the three post-formation years. Panel B reports each portfolio's average return in excess of the equally-weighted return on a control portfolio of stocks matched by firm size and book-to-market in the first through third post-formation years. Panel $\mathrm{C}$ reports characteristics of the portfolios: the average number of component stocks; the ratios of advertising expenditures to market value of equity and to sales; book value of equity relative to market value of equity; sales relative to market value of equity; earnings relative to market value of equity; annual dividends divided by market value of equity; and the natural logarithm of market value of equity in millions of dollars.

\begin{tabular}{|c|c|c|c|c|c|c|}
\hline & 1 (Low) & 2 & 3 & 4 & 5 (High) & $\begin{array}{c}\text { Non- } \\
\text { advertising }\end{array}$ \\
\hline \multicolumn{7}{|c|}{ Panel $A:$ Returns before and after portfolio formation } \\
\hline $\begin{array}{l}\text { Average annual return over } 5 \text {-year } \\
\text { period before portfolio formation }\end{array}$ & 0.3146 & 0.2286 & 0.1978 & $0.1 \overline{769}$ & 0.1402 & 0.1981 \\
\hline First year after portfolio formation & 0.1651 & 0.1958 & 0.2179 & 0.2246 & 0.2276 & 0.1946 \\
\hline Second year after portfolio formation & 0.1491 & 0.1945 & 0.2113 & 0.2045 & 0.2321 & 0.1886 \\
\hline Third year after portfolio formation & 0.1648 & 0.1972 & 0.2189 & 0.2196 & 0.2491 & 0.1854 \\
\hline $\begin{array}{l}\text { Average annual return over } 3 \text {-year } \\
\text { period after portfolio formation }\end{array}$ & 0.1597 & 0.1958 & 0.2160 & 0.2162 & 0.2363 & 0.1895 \\
\hline \multicolumn{7}{|c|}{ Panel B: Excess returns after portfolio formation } \\
\hline First year after portfolio formation & -0.0103 & 0.0037 & 0.0215 & 0.0266 & 0.0187 & -0.0028 \\
\hline Second year after portfolio formation & -0.0085 & 0.0168 & 0.0272 & 0.0150 & 0.0295 & 0.0036 \\
\hline Third year after portfolio formation & 0.0042 & 0.0189 & 0.0325 & 0.0264 & 0.0447 & 0.0000 \\
\hline $\begin{array}{l}\text { Average annual excess return over } \\
3 \text {-year period after porfolio formation }\end{array}$ & -0.0049 & 0.0131 & 0.0271 & 0.0227 & 0.0310 & 0.0003 \\
\hline \multicolumn{7}{|c|}{ Panel C: Characteristics of portfolios } \\
\hline Average & 231.6 & 231.7 & 232.0 & 232.2 & 232.3 & 1887.7 \\
\hline Advertising to sales & 0.0162 & 0.0181 & 0.0252 & 0.0342 & 0.0666 & 0.0000 \\
\hline Advertising to market value & 0.0049 & 0.0159 & 0.0341 & 0.0707 & 0.2011 & 0.0000 \\
\hline Book-to-market & 0.4723 & 0.6429 & 0.7804 & 0.9191 & 1.1760 & 0.8757 \\
\hline Sales-to-market & 1.0028 & 1.5605 & 2.1899 & 3.1984 & 4.9396 & 2.5053 \\
\hline Earnings-to-price & 0.0414 & 0.0629 & 0.0659 & 0.0715 & 0.0731 & 0.0758 \\
\hline Dividend yield & 0.0096 & 0.0152 & 0.0190 & 0.0219 & 0.0231 & 0.0261 \\
\hline Log Size & 4.5883 & 4.5264 & 4.5185 & 4.4813 & 3.8427 & 4.5434 \\
\hline
\end{tabular}

